\title{
VARIAÇÃO SOMACLONAL EM CARACTERES AGRONÔMICOS EM PROGÊNIES DE PLANTAS DE ARROZ REGENERADAS \\ A PARTIR DE PROTOPLASTOS
}

\author{
EDSON FERREIRA DA SILVA
}

Biólogo

ORIENTADOR: Prof. Dr. AKIHIKO ANDO

Tese apresentada à Escola Superior de Agricultura "Luiz de Queiroz", Universidade de São Paulo, para obtenção do título de Doutor em Agronomia, Área de concentração: Genética e Melhoramento de Plantas.

\section{PIRACICABA}

Estado de São Paulo

Abril - 1999 
Dados Internacionais de Catalogação na Publicação (CIP) DIVISÃo DE BIBLIOTECA E DOCUMENTAÇÃO - Campus "Luiz de Queiroz"/USP

Silva, Edson Ferreira da

Variação somaclonal em caracteres agronômicos em progènies de plantas de arroz regeneradas a partir de protoplastos / Edson Ferreira da Silva. - - Piracicaba, 1999.

87 p. : il.

Tese (doutorado) - - Escola Superior de Agricultura Luiz de Queiroz, 1999. Bibliografia.

1. Arroz de sequeiro 2. Melhoramento genético vegetal 3. Progènie vegetal 4. Protoplasto 5. Variação somaclonal I. Título

CDD 633.18 
SILVA, E.F. Variação somaclonal em caracteres agronômicos em progênies de plantas de arroz regeneradas a partir de protoplastos. 1999, 87p.

\section{ERRATA}

\begin{tabular}{|c|c|c|c|}
\hline Página & Linha & Onde se lê & Leia-se \\
\hline 7 & 19 & ...de 22 espécies... & ...de 23 espécies... \\
\hline 27 & 12 & ...rendimento e tipo de grão.. & $\begin{array}{l}\text {...rendimento de grão } \\
\text { inteiro e tipo de grão... }\end{array}$ \\
\hline 70 & 3 & ...peso de 100 mil grãos... & ...peso de 1.000 grãos... \\
\hline 70 & 9 & $\begin{array}{c}\text {...utilizando-se esse } \\
\text { delineamento, deve-se.... }\end{array}$ & $\begin{array}{l}\text {...utilizando-se o delineamento } \\
\text { de blocos aumentados, deve-se.. }\end{array}$ \\
\hline
\end{tabular}


À Deus por ter dado saúde e perseverância para superar as dificuldades encontradas na busca desse objetivo;

Agradeço

Ao meu pai Nelci, que mesmo sem ter uma boa escolaridade proporcionou-me a formação necessária para o meu desenvolvimento cultural.

À minha mãe Rosalva (in memorian) que mesmo saindo do nosso convivio ainda na minha infância, deixou e permaneceu cuidando de parte do seu patrimônio genético atribuído a mim com desejos de prosperidade;

\section{Ofereço}

À minha esposa Gílcia pelo apoio, carinho, companheirismo, compreensão e empenho de fundamental importância nesta etapa de minha vida.

À minha filha Gabriela, fonte de inspiração e renovação de esperança a cada dia.

\section{Dedico}




\section{AGRADECIMENTOS}

Ao Prof. Dr. Akihiko Ando, pela orientação, pelos ensinamentos, estímulos, exemplo, disponibilidade sem restrição de horário ou dia da semana e pela grande amizade estabelecida.

Ao Conselho Nacional de Desenvolvimento Científico Tecnológico (CNPq), pela concessão de bolsa de estudo para a realização do curso.

Aos professores do Departamento de Genética pelos conhecimentos proporcionados e amizade estabelecida.

Aos alunos do Curso de Pós Graduação do Departamento de Genética, pela convivência, amizade, prestabilidade e aprendizado.

Ao Leonardo Novaes Rosse e Marcelo Tavares pela grande amizade e auxilios imprescindiveis prestados nas minhas dificuldades para finalizar este trabalho.

À Bibliotecária Silvana M. Gregório pela revisão das normas bibliográficas e excelente atendimento prestado em sua função.

Aos meus familiares principalmente os que estiveram mais próximo Ana Antunes, Francisco, Genny, Cláudio, Marta, Florindo, Iraci, Iracema, José, Agnaldo, Laerte e Elizabete, que direto ou 
indiretamente participaram proporcionando estabilidade e harmonia familiar.

Aos pesquisadores Drs. Cândido Ricardo Bastos e Luiz Ernesto Azzini pela amizade e sugestões dadas.

Aos todos os funcionários do Departamento de Genética, em especial a Neuza, Carmem, Macedonio, Cláudio Segatelli, Aparecido, Léia, Valdir, "Oberdan", Fernando e Silvana.

Aos funcionários Amaral e Antônio que participaram diretamente na condução dos experimentos.

Aos funcionários da seção de Genética e Melhoramento Vegetal do CENA/USP em especial a Inês, José, Paulo e Vlamir pela amizade e prestatividade nas atividades que foram realizadas conjuntamente. 


\section{SUMÁRIO}

Página

LISTA DE FIGURAS ........................................................ vi

LISTA DE TABELAS............................................................ vii

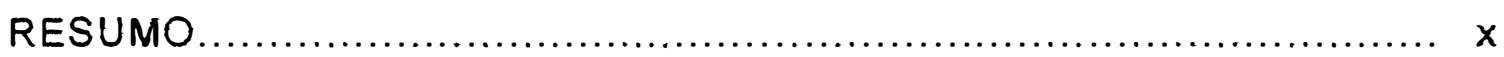

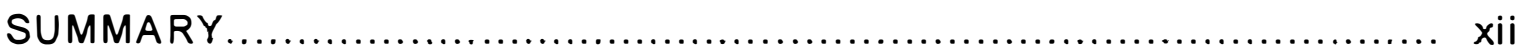

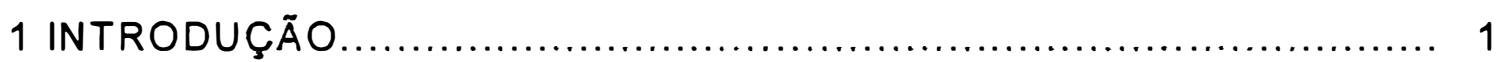

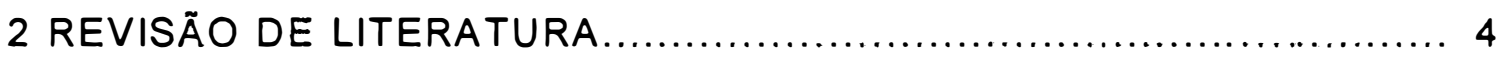

2.1 Aspectos gerais da cultura do arroz .............................. 4

2.1 .1 No Mundo............................................................. 4

2.1.2 No Brasil.................................................................. 5

2.2 Melhoramento do arroz no Brasil.................................... 7

2.3 Utilização e potencialidades do cultivo in vitro no 14 melhoramento.

2.4 Variação somaclonal................................................ 16

2.4.1 Causas e base genética da variação somaclonal................... 16

2.4.1.1 Alterações no número e estrutura dos cromossomos.............. 18

2.4.1.2 Hipo e hipermetilação do DNA................................... 20

2.4.1.3 Ativação de elementos transponíveis.............................. 21

2.4.1.4 Modificações no DNA citoplasmático.............................. 23

2.5 Aplicação da variação somaclonal no melhoramento de 25 plantas.

2.6 Variação somaclonal no melhoramento do arroz ..................... 27

3 MATERIAL E MÉTODOS............................................... 30

3.1 Material................................................................. 30 
3.2 Condução dos experimentos......................................... 33

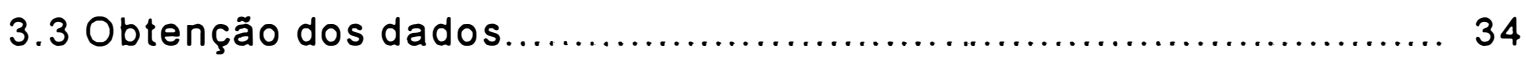

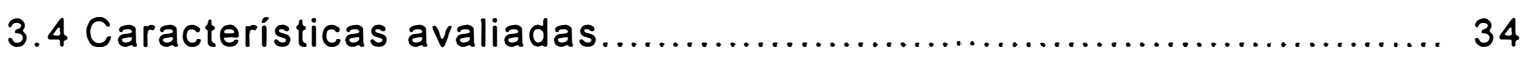

3.4.1 Número de dias até o florescimento (CICLO) ..................... 34

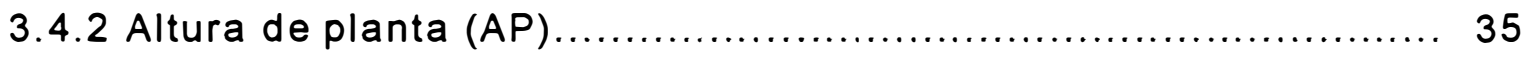

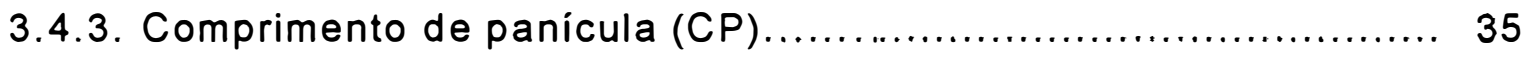

3.4.4 Número de espiguetas por panícula (NEP) ....................... 35

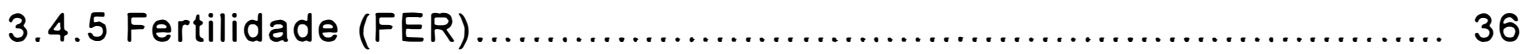

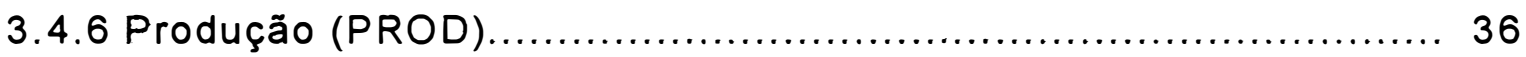

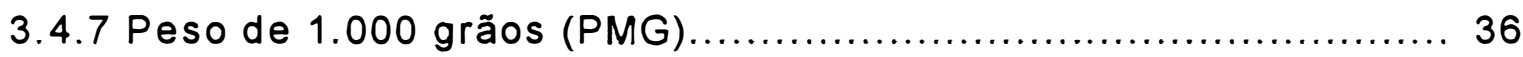

3.5 Análises estatísticas......................................... 37

3.6 Estimativas dos parâmetros genéticos ............................ 40

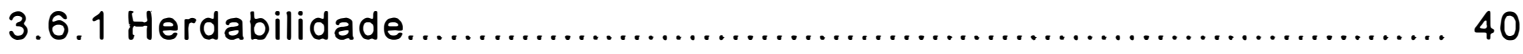

3.6.2 Coeficiente b.................................................. 41

3.7 Critério de agrupamento de médias de SCOTT-KNOTT.............. 41

4 RESULTADOS E DISCUSSÃO ......................................... 43

4.1 Análises estatísticas.......................................... 43

4.2 Estimativas dos parâmetros genéticos .............................. 55

4.3 Critério de agrupamento de médias de SCOTT-KNOTT.............. 65

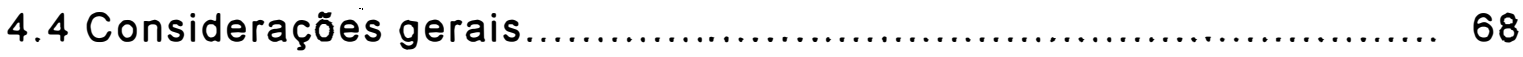

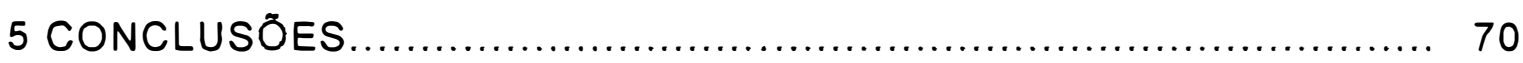

REFERÉNCIAS BIBLIOGRÁFICAS ................................... 71 


\section{LISTA DE FIGURAS}

Página

1 Sementes das cultivares originais IAC 165 (a), IAC 201 (c) e variantes da IAC 165 em (b) e da IAC 201 em (d).......... 49

2 Paniculas da cultivar original IAC 165 (a) e panícula adensada de progênie variante em (b) ...................... 55 


\section{LISTA DE TABELAS}

Página

1 Relação do número de plantas regeneradas e conduzidas da primeira geração $\left(R_{1}\right)$ à quarta geração $\left(R_{4}\right) \ldots \ldots \ldots \ldots \ldots . . . \ldots 33$

2 Esquema da análise de variância em blocos aumentados utilizando o erro intrabloco..................................... 38

3 Resumo das análises de variância dos caracteres avaliados no experimento conduzido com as progênies $R_{3}$ da cultivar IAC 201 no ano agrícola de 1996/97

4 Resumo das análises de variância dos caracteres avaliados no experimento conduzido com as progênies $R_{3}$ da cultivar IAC 201 no ano agrícola de 1997/98.

5 Resumo das análises de variância dos caracteres avaliados no experimento conduzido com as progênies $R_{3}$ da cultivar IAC 165 no ano agrícola de 1996/97

6 Resumo das análises de variância dos caracteres avaliados no experimento conduzido com as progênies $R_{4}$ da cultivar IAC 165 no ano agrícola de 1997/98 
7 Estimativas dos parâmetros genéticos: variância genética $\left(\sigma_{\mathrm{g}}^{2}\right)$, coeficiente de variação genético $(\mathrm{CVg})$, índice b (b) e herdabilidade $\left(h^{2}\right)$, para os caracteres avaliados no experimento conduzido com as progênies $R_{3}$ da cultivar IAC 201 no ano agrícola de 1996/97.

8 . Estimativas dos parâmetros genéticos: variância genética $\left(\sigma_{\mathrm{g}}^{2}\right)$, coeficiente de variação genético $(\mathrm{CVg})$, índice $\mathrm{b}(\mathrm{b})$ e herdabilidade $\left(h^{2}\right)$, para os caracteres avaliados no experimento conduzido com as $R_{3}$ progênies da cultivar IAC 201 no ano agrícola de 1997/98.

9 Valores de coeficiente de variação genético ( $\mathrm{CVg}$ ) estimados nos anos agrícolas de 1996/97 e 1997/98 e valor da alteração da variabilidade entre os dois anos para as progênies do cultivar IAC 201

10 Estimativas dos parâmetros genéticos: variância genética $\left(\sigma_{g}^{2}\right)$, coeficiente de variação genético $(C V g)$, índice $b(b)$ e herdabilidade $\left(h^{2}\right)$, para os caracteres avaliados no experimento conduzido com as progênies $R_{3}$ da cultivar IAC 165 no ano agrícola de 1996/97............................

11 Estimativas dos parâmetros genéticos: variância genética $\left(\sigma_{\mathrm{g}}^{2}\right)$, coeficiente de variação genético $(\mathrm{CVg})$, indice $b(\mathrm{~b})$ e herdabilidade $\left(h^{2}\right)$, para os caracteres avaliados no experimento conduzido com as progênies $R_{4}$ da cultivar 


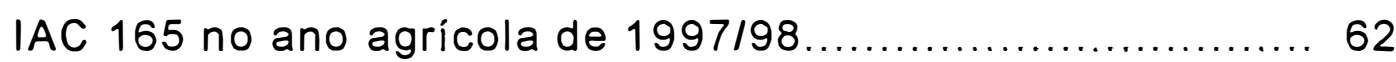

12 Valores de coeficiente de variação genético ( $\mathrm{CVg}$ ) estimados nos anos agrícolas de 1996/97 e $1997 / 98$ e valor da alteração da variabilidade entre os dois anos para as progênies do cultivar IAC 165

13 Relação das progênies das cultivares IAC 165 e IAC 201 que diferiram estatisticamente das originais para 0 caráter FER com suas respectivas médias agrupadas pela metodologia de SCOTT-KNOTT e sua diferença em relação às testemunhas nos anos agrícolas de 1996/97 e 1997/98.. 66

14 Relação das progênies das cultivaras IAC 165 e IAC 201 que diferiram estatisticamente das originais para 0 caráter PMG com suas respectivas médias agrupadas pela metodologia de SCOTT-KNOTT e sua diferença em relação às testemunhas 


\title{
VARIAÇÃO SOMACLONAL EM CARACTERES AGRONÔMICOS EM PROGÊNIES DE PLANTAS DE ARROZ REGENERADAS A PARTIR DE PROTOPLASTOS
}

\author{
Autor: EDSON FERREIRA DA SILVA \\ Orientador: Prof. Dr. AKIHIKO ANDO
}

\section{RESUMO}

O melhoramento do arroz no Brasil é uma atividade recente. Todas as cultivares recomendadas, até então, foram obtidos por metodologias convencionais de recombinação seguida de seleção, ou por introdução. A variabilidade genética é um requisito de fundamental importância para que sejam selecionados genótipos a serem recomendados como cultivares. Neste contexto, a variação somaclonal é uma das metodologias não convencionais que poderão contribuir para essa finalidade. $O$ presente trabalho foi desenvolvido com a finalidade de avaliar e selecionar possiveis variantes, decorrentes de variação somaclonal, para caracteres agronômicos em progênies de plantas regeneradas de protoplastos de escutelo de sementes germinadas das cultivares de arroz de sequeiro IAC 201 e IAC 165. As progênies das cultivares foram avaliadas nas gerações R3 e R4 em experimentos distintos delineados em blocos aumentados durante os anos agrícolas de $1996 / 97$ e 1997/98. Os blocos foram constituídos de 30 tratamentos, dos quais três eram testemunha IAC 165, IAC 201 e Guarani. As progênies foram avaliadas quanto ao ciclo ate 0 florescimento, altura de planta, comprimento de panícula, número de espiguetas por panícula, fertilidade, produção e peso de 1000 grãos. Através da análise de variância, detectou-se diferenças 
significativas apenas para os caracteres fertilidade e peso de mil grãos para as progênies de ambas as cultivares.

No entanto, as que mostraram alterações para fertilidade tiveram redução do caráter em relação às cultivares originais, sendo portanto indesejáveis para o melhoramento. Já as alterações para peso de 1000 grãos ocorreram nas mesmas progênies que tiveram alteração para fertilidade. Os grãos tornaram-se maiores e com arista, tendo manifestação fenotípica de poliplóides. Os CVs foram, de um modo geral, de magnitude baixa a intermediária. Estes resultados permitem inferir que para estudos com essa finalidade, utilizando-se esse delineamento, deve-se dar preferência ao uso de parcelas de tamanho maior no sentido de aumentar a precisão experimental, já que não há repetição dos tratamentos regulares. Os coeficientes de herdabilidade variaram de médio a baixo dependendo do caráter, sendo os maiores valores estimados para fertilidade e peso de mil grãos nas progênies de ambas as cultivares nos respectivos anos agrícolas e o menor para ciclo até o florescimento. O índice b mostrou-se também, como já era de se esperar, valores abaixo da unidade para todos os caracteres. Os valores obtidos para os parâmetros genéticos são indicativos da baixa variabilidade genética disponivel nesses caracteres, inferindo-se assim que a regeneração de plantas a partir de protoplastos de escutelo primário destas duas cultivares num período de cultivo in vitro de aproximadamente 60 dias não gerou variabilidade esperada para os caracteres de interesse agronômico estudados. 


\title{
SOMACLONAL VARIATION OF AGRONOMICAL TRAITS IN PROGENIES OF RICE PLANTS REGENERATED FROM PROTOPLASTS
}

\author{
Author: Edson Ferreira da Silva \\ Adviser: Prof. Dr. Akihiko Ando
}

\section{SUMMARY}

Rice breeding was initiated in Brazil fairly recently. All recommended varieties for cultivation were obtained through conventional methods of recombination followed by selection, or through introduction. To select genotypes that could be recommended as cultivars, genetic variability is of fundamental importance. Somaclonal variation is one of the non-conventional breeding methods that may contribute to that goal. The present work was carried aut to evaluate and select variants in agronomical traits deruved from somaclonal variation, present in rice plants that were regenerated from protoplasts isolated from the scutellum of germinating seeds of upland rice cultivars IAC 201 and IAC 165. Their progenies were evaluated during the R3 and R4 generations, in separate experiments with augmented block desing during the growing seasons of $1996 / 1997$ and 1997/1998. Each block consisted of 30 treatments, and the cultivars IAC 165, IAC 201, and Guarani were used as controls. The progenies were evaluated in regard to flowering cycle, plant height, panicle size, number of spikelets per panicle, fertility, yield, and weight of 1,000 grains.

Variance analysis could detected significant differences only in fertility and weight of 1,000 grains. Grains of these progenies showed larger size and possessed arista, typical 
manifestations of polyploidy. Such results indicate that theses progenies are undesirable for breeding purposes. In general, the coefficients of variation were of low to intermediate magnitude. These results suggest that, for studies using a statistical design similar to the one employed in the present work, the use of larger plots is necessary to increase experimental precision, considering that there were no replications of regular treatments. Heritability coefficient values ranged from medium to low for different traits: higher estimated values were observed for fertility and weight of 1,000 grains for both cultivars during both growing seasons, and lower values observed for flowering cycle. As was expected, the $b$ values were lower than 1.0 for all traits. The $b$ values obtained for genetic traits are indicate the presence of low genetic variability, suggesting that the regenerated plants from protoplasts isolated from primary scutellum calli of the two cultivars under investigation, which were cultivated in vitro for 60 days, did not allow the detection of sufficient variability in the agronomical traits evaluated. 


\section{INTRODUÇÃO}

O arroz (Oryza sativa L.) constitui a base alimentar dos povos asiáticos e americanos. No Brasil, esta cultura tem grande importância econômica e social, onde o consumo per capita é estimado em $75 \mathrm{Kg} /$ habitante/ano (Agrianual, 1998). O cultivo é feito basicamente sob quatro sistemas: irrigado, várzea úmida, sequeiro e sequeiro favorecido. Apesar de todo território brasileiro apresentar potencialidade para produzir arroz, a produção nacional não atende as necessidades de consumo. Isto ocorre devido a produtividade média, principalmente nos sistemas de várzea úmida e de sequeiro, ser baixa, o que coloca o país na condição de importador do produto.

0 desenvolvimento de novas cultivares mais apropriadas aos sistemas de cultivos, por exemplo com melhor qualidade de grão e tolerância e/ou resistência à estresse biótico e abiótico, é a alternativa mais viável para se elevar os patamares de produtividade estimulando assim, o aumento da produção e, no futuro tornar o país auto suficiente em relação a produção de arroz.

Especificamente em relação ao sistema de cultivo de sequeiro, que tem maior área plantada no Brasil, a baixa produtividade deve-se principalmente a falta de cultivares com adaptabilidade às regiões microclimáticas específicas. Para este sistema de cultivo, objetiva-se cultivares de porte baixo, para evitar perdas decorrentes do acamamento, ciclo precoce, para evitar os 
periodos de veranicos e com qualidade e tipo de grão que alcance os preços obtidos com os produtos das cultivares irrigadas, além de outras características agronômicas favoráveis.

Para tanto, a geração e aproveitamento da variabilidade genética, para seleção de genótipos transgressivos, nos programas de melhoramento, são imprescindiveis. A hibridação controlada para obter recombinantes entre parentais divergentes e complementares, é a metodologia mais utilizada e que tem proporcionado maior objetividade para geração de variabilidade nos programas de melhoramento do arroz. No entanto, outras metodologias ou fontes de variabilidade como: mutação espontânea, mutação induzida, hibridação somática, variação somaclonal e mais recentemente, a transferência direta de genes através de técnicas de engenharia genética, têm sido utilizadas e se mostrado eficientes para geração de variabilidade.

O uso da variação somaclonal tem sido apontado como uma alternativa no melhoramento de espécies de reprodução sexuada como o arroz, pois na variação somaclonal, assim como na mutação induzida, a variabilidade é gerada de maneira aleatória. Portanto, são mais indicadas para a correção de defeitos em genótipos elites. No entanto, o cultivo in vitro tem gerado um grande número de variantes de arroz, que possam ser aplicados com a finalidade de gerar variabilidade ou indiretamente em pesquisas com outros objetivos, como por exemplo, cultura de antera visando obtenção de linhagens homozigotas e culturas objetivando a transformação genética. Já no início da década de 90, Zongxio et al. (1991) relacionaram cerca de 36 cultivares de arroz melhoradas, tanto para caracteres qualitativos como quantitativos, selecionadas de variação somaclonal. Os variantes somaclonais, assim como os obtidos por métodos convencionais, 
podem ser explorados diretamente como cultivares ou serem utilizados na recombinação em programas de melhoramento.

O presente trabalho teve por objetivo avaliar a variabilidade quanto aos caracteres agronômicos, decorrentes de variação somaclonal em progênies $R_{3}$ e $R_{4}$, provenientes das plantas regeneradas a partir de protoplastos de calos escutelares primários das cultivares de arroz de sequeiro IAC 165 e IAC 201, e identificar materiais promissores para seleção de genótipos superiores ou seu uso em programas de melhoramento. 


\section{REVISÃO DE LITERATURA}

\subsection{Aspectos gerais da cultura do arroz}

\subsubsection{No Mundo}

O arroz é uma das culturas de máxima importância para o suprimento da crescente demanda de alimento mundial. $O$ produto constitui a base alimentar principalmente dos povos asiáticos e das comunidades americanas.

As médias mundiais de produção anual e de área plantada, nos últimos oito anos, foram respectivamente de 539,687* milhões de toneladas e $147,632^{*}$ milhões de hectares. Com estas médias, a cultura do arroz ocupa o segundo lugar em área plantada, sendo superada apenas pelo trigo (FAO, 1997).

Quatro sistemas de cultivo, são utilizados para produção do arroz: irrigado, várzea úmida, sequeiro e sequeiro com irrigação suplementar, sendo que a área plantada em cada sistema é de $55 \%, 25 \%, 12 \%$ e $8 \%$, respectivamente (Khush, 1997).

Apesar de ser cultivado basicamente em todos os continentes, os países asiáticos têm as maiores áreas plantadas e as maiores produções.

\footnotetext{
* Médias calculadas de AGRIANUAL, (1998)
} 
Somente a China e Índia representam 50\%* da área plantada e $57,1 \%$ da produção mundial. Sendo que na China cerca de $90 \%$ do cultivo é feito no sistema irrigado e na Índia em torno de $46 \%$. As maiores médias de produtividade nos últimos oito anos foram obtidas na Austrália $\left(8,256^{\star} t / h a\right)$, onde o cultivo exclusivamente sob sistema irrigado.

Quanto ao consumo per capita, a média mundial nos últimos dez anos foi de $64,33^{\star} \mathrm{Kg} / \mathrm{ano}$. Segundo Khush (1997), este consumo tem aumentado em média $1,8 \%$ ao ano. Deve-se considerar ainda, que nos paises asiáticos e em alguns países americanos, inclusive no Brasil, o consumo per capita médio é significativamente superior à média mundial.

Além do consumo na dieta básica, o arroz é utilizado ainda para outras finalidades, embora em pequenas proporções, por exemplo: como matéria prima na indústria de cola, para extração de amido e óleo, e "casca" de grão e palha como fonte alternativa de celulose para fabricação de papel.

\subsubsection{No Brasil}

No Brasil, o arroz constitui a base alimentar da população. O consumo médio e o consumo per capita anual, nos últimos dez anos, foi estimado em $11,274^{*}$ milhões de toneladas e $75^{*} \mathrm{Kg}$, respectivamente. A produção média anual foi estimada em $10,216^{*}$ milhões de toneladas no mesmo período, sendo portanto deficitária em $1,058^{*}$ milhões de toneladas anualmente.

\footnotetext{
* Médias calculadas de AGRIANUAL, (1998)
} 
Apesar do cultivo do arroz ser feito basicamente em todo território nacional, e o país apresentar grandes potencialidades para a sua expansão, o déficit de produção tem colocado o Brasil na condição de importador do produto, principalmente do Uruguai e da Argentina.

Segundo Rangel (1990), a rizicultura brasileira é conduzida sob quatro sistemas de cultivo principais: i) irrigado; arroz inundado com irrigação controlada, ii) várzea úmida; sem irrigação controlada, iii) sequeiro; arroz de terras altas e iv) sequeiro favorecido; arroz de terras altas com irrigação suplementar.

Quanto a área plantada e a produção média, o sistema irrigado representa $30 \%$ da área plantada, $55,5 \%$ da produção nacional, mostrando produtividade média de 4,5 toneladas por hectare, e é predominante no Rio Grande do Sul.

O sistema de sequeiro, incluindo-se também 0 sistema de sequeiro favorecido, representa $66 \%$ da área plantada e $41,5 \%$ da produção nacional, e tem produtividade média de 1,9 toneladas por hectare, sendo predominante nas regiões Sudeste e Centro Oeste.

Já o sistema de várzea úmida representa apenas $4 \%$ da área plantada, $3 \%$ da produção nacional, tem produtividade média de 1,9 toneladas por hectare e restringe-se a áreas de vazante sem possibilidade de sistematização de irrigação.

A produtividade média nacional, que situa na faixa de $2,667 \mathrm{Kg} / \mathrm{ha}$ (FAO, 1997) é considerada baixa. Isto deve-se, não somente ao manejo inadequado da cultura em algumas regiões, mas também à carência de um número maior de cultivares adaptadas aos sistemas de cultivo e as regiões específicas de plantio. 
Especificamente em relação ao sistema de cultivo de sequeiro, além da demanda por cultivares mais adaptadas a esta condição e com patamares de produtividade mais elevados, existe ainda uma demanda por cultivares que apresentem qualidade e tipo de grãos que possam alcançar os preços de mercado comparáveis com o produto das cultivares utilizadas em áreas irrigadas. Este fator tem desestimulado o plantio e os investimento neste sistema de cultivo.

O desenvolvimento de novas cultivares adequadas aos sistemas de cultivo, com adaptabilidade às diversas regiões e que apresentem tolerância tanto às condições ambientais estressantes, como também resistência a pragas e patógenos, constitui a estratégia mais viável para o aumento tanto da produtividade como da área plantada. Estes procedimentos podem fazer com que o Brasil possa obter produções capazes de suprir a demanda de consumo interno de arroz e assim, potencializar a produção inclusive objetivando a exportação.

\subsection{Melhoramento do arroz no Brasil}

O gênero Oryza é composto de 22 espécies, sendo duas cultivadas: 0 . glaberrima Steud. $\left(2 n=24, A^{9} A^{9}\right)$ de origem africana, que é cultivada no Oeste da África e O. sativa L. $(2 n=24$, AA) de origem asiática, cultivada em todo o mundo (Khush, 1997). Portanto, quase todas as cultivares de arroz do mundo são oriundas de 0 . sativa L., que é também a espécie cultivada no Brasil. Segundo Mckenzie et al. (1987), esta espécie possui três grupos ecogeográficos distintos: Japônica que é o grupo de clima temperado, Índica de clima tropical e Javânica que é intermediário entre os dois primeiros, o qual acredita-se que tenha sido 
desenvolvido na Indonésia. Atualmente, a distinção entre estes grupos tem se tornado cada vez mais difícil em decorrência do alto fluxo gênico entre os três, proporcionado pelas hibridações controladas nos programas de melhoramento.

O cultivo do arroz no Brasil, ao que tudo indica, teve inicio durante a colonização do pais pelos portugueses. No entanto, há controvérsias quanto ao modo e a época exata da introdução (Angladette, 1963). Segundo Cascudo (1983), já em 1573 havia notícia da existência de muito arroz distribuido da Bahia até o Sul do país.

$\mathrm{Na}$ forma de mistura de variedades, genótipos introduzidos expandiram-se por todo o pais, permanecendo em cultivo até meados da década de 30 deste século.

Portanto, as pesquisas de melhoramento do arroz no Brasil são atividades recentes e que tiveram inicio no Instituto Agronômico de Campinas (IAC) em 1936, através dos pesquisadores H. S. Miranda e E. B. Germek. Os dois pesquisadores iniciaram seus trabalhos selecionando e testando variedades cultivadas no Estado de São Paulo (Viégas et al., 1945). No ano anterior, Miranda e Germek fizeram a primeira multiplicação de sementes das variedades Dourado Agulha, Iguape, Jaguari e Cateto. Os ensaios de competição foram iniciados em 1936, objetivavando-se o cultivo irrigado na região de Pindamonhangaba e o sequeiro na região de Pindorama. Foram estudadas as seguintes variedades: Dourado Agulha, Iguape Agulha, Jaguari, Cateto, Pérola, Fortuna e Honduras, sendo que as variedades Iguape Agulha e Cateto foram selecionadas dentro da Iguape. Destes estudos, estabeleceu-se a melhor época e condição de cultivo, e a cultivar Pérola destacou-se como a melhor entre as variedades testadas (Viégas et al., 1945). Portanto, o 
melhoramento do arroz no Brasil teve início de maneira brilhante, explorando a variabilidade dos genótipos já disponiveis.

Os trabalhos de hibridação iniciaram-se em 1938 através do pesquisador Germek, (Viégas et al., 1945). A introdução de germoplasma de outros países também forneceu importante subsídio ao programa de melhoramento do IAC. Até 1945, haviam sido introduzidas, pelo IAC, 372 variedades de paises como: Estados Unidos, Índia, Ceilão, Colômbia, Itália, Guiana Inglesa, Filipinas, Áustria, Java, Guiana Holandesa, Peru, Tailândia e também de outros pontos do Brasil (Viégas et al., 1945).

Também em 1938, iniciou-se no Rio Grande do Sul, através do Instituto Riograndense de Arroz (IRGA), o programa de melhoramento objetivando o cultivo irrigado (Resende, 1976). A exemplo do IAC, o IRGA inicialmente procedeu introduzindo grande número de genótipos dos Estados Unidos, depois do Japão, Itália, Formosa e Filipinas (Cutrim, 1994), passando a fazer hibridações posteriormente.

No IAC, as primeiras cultivares provenientes da seleção entre as populações segregantes, obtidas de cruzamentos, foram liberadas durante a década de 50 (Cutrim, 1994). Entre os vários genótipos importantes liberados neste periodo, estão: IAC 1 (Matão x Pérola), IAC 3 (Jaguari x lola), IAC 4 (Pratão x Pérola), IAC 5 (Dourado Agulha $x$ Dourado Peludo), IAC 7 (Dourado Peludo $x$ Fortuna), IAC 8 (Pratão $x$ (Pérola $x$ Cateto) e IAC 9 (Iguape Agulha X Nira) (Germek \& Banzatto, 1972).

Vale ressaltar que das primeiras cultivares selecionadas de cruzamentos, destacou-se a IAC $1246 \mathrm{com}$ aproximadamente $60 \%$ da área plantada com arroz de sequeiro no país na década de 60 (Germek \& Banzatto, 1977). Além de participar da genealogia de várias cultivares modernas, esta 
cultivar continua sendo recomendada para o sistema de sequeiro no Estado de Santa Catarina (EMBRAPA, 1997).

No IRGA, as primeiras cultivares obtidas do programa de hibridação foram liberadas em 1959, sendo que a primeira cultivar de sucesso foi a EEA 404, selecionada do cruzamento entre os genótipos americanos Zenith e Maravilha 1 e lançada em 1961 (Cutrim, 1994).

Até o início da década de 70, basicamente o IAC e o IRGA faziam melhoramento do arroz no Brasil, sendo que o IAC desenvolvia cultivares de sequeiro e irrigada e o IRGA apenas cultivares irrigadas. Neste período, a maioria das cultivares recomendadas no país eram do tipo tradicional; de porte alto, folhas decumbentes, tipo de grão longo e ciclo longo, com exceção de alguma cultivares de sequeiro que tinham ciclo médio e precoce. Segundo Carmona (1989), a utilização de cultivares irrigadas modernas, de ciclo precoce, porte baixo e com tipo e qualidade de grão no padrão atual, teve início em 1972 com a introdução de cultivares americanas, especialmente a Bluebelle.

Com relação as cultivares de sequeiro, estas mudanças ainda estão ocorrendo, em decorrência das perdas ocasionadas por acamamento e o baixo preço obtido pelo produto de tipo de grão longo em relação ao longo-fino. As cultivares de sequeiro tradicionais estão sendo aos poucos substituídas por cultivares modernas que tenham porte baixo e tipo de grão longofino, as quais alcançam os mesmos preços obtidos com o produto das cultivares irrigadas.

Durante a década de 70, o melhoramento do arroz no Brasil teve grande impulso com implantação de programas de melhoramento em outros Estados, como por exemplo o IAPAR no Paraná, EPAMIG em Minas Gerais e a fundação do Centro Nacional 
de Pesquisa de Arroz e Feijão (CNPAF) da EMBRAPA em Goiânia, Goiás. Através do CNPAF, aumentou-se o intercâmbio de materiais e informações entre as equipes de pesquisadores do arroz.

Em 1982, foram criadas as Comissões Técnicas Regionais de Arroz (CTArroz) que subdividiram as pesquisas em três Regiões: Região I inclui os Estados do Rio Grande do Sul e Santa Catarina, Região ll correspondente aos Estados da região Sudeste, Centro Oeste mais os Estados da Bahia e Paraná e Região III correspondente aos demais Estados do Norte e Nordeste (EMBRAPA, 1994). Através destas comissões, uniformizou-se os objetivos principais dos programas de melhoramento para cada região e estabeleceu-se critérios para recomendação de cultivares.

Atualmente, seis Instituições desenvolvem programas completos de melhoramento do arroz no Brasil (da hibridação à liberação de cultivares): Instituto Agronômico de Campinas (IAC); Instituto Agronômico do Paraná (IAPAR), Centro Nacional de Pesquisa de Arroz e Feijão (CNPAF), Instituto Riograndense do Arroz (IRGA), Centro de Pesquisa Agropecuária de Clima Temperado (CPACT) com sede em Pelotas, RS e a "Fazenda Quatro Irmãos" da iniciativa privada também com sede em Pelotas, sendo que as três primeiras estudam tanto cultivares de sequeiro como as irrigadas e as três últimas objetivam apenas cultivares para sistema irrigado, segundo Guimarães, (1999)"*. Além das Instituições mencionadas, existem outras estaduais, como por exemplo: Empresa de Pesquisa Agropecuária de Minas Gerais (EPAMIG), Empresa de Pesquisa Agropecuária e Extensão Rural de Santa Catarina (EPAGRI) e Empresa Goiana de Pesquisa Agropecuária (ENGOPA), que selecionam e testam genótipos

\footnotetext{
** Guimarães, E.P. - CNPAF/EMBRAPA, informação pessoal, 1999.
} 
provenientes de outras Instituições, objetivando a introdução em seus Estados.

Quanto aos objetivos gerais, os programas de melhoramento do arroz no Brasil visam desenvolver cultivares com maior produtividade, resistência a enfermidades, principalmente a brusone que é a principal doença da rizicultura brasileira, porte baixo para possibilitar melhor uso de fertilizantes sem riscos de acamamento, bom perfilhamento e alto rendimento de engenho. Quanto as características de grão, objetiva-se classe longo-fino, vítreo e com teor de amilose intermediário (21-25\%) que proporciona boa cocção (Guimarães, 1989).

Especificamente para o sistema de sequeiro, além das características já mencionadas, objetiva-se também cultivares com tolerância a estresse hídrico e para as regiões de cerrado também tolerância a estresse mineral.

Por ser uma espécie autógama, com menos de $1 \%$ de fecundação cruzada, o melhoramento do arroz no Brasil objetiva o desenvolvimento de cultivares homozigóticas. No entanto, o CNPAF vem desenvolvendo projetos de pesquisas objetivando viabilizar a produção de sementes híbridas com finalidade comercial (Neves et al., 1994).

A maioria das cultivares recomendadas no Brasil foi obtida por introdução de cultivares ou de linhagens avançadas, elou por hibridação seguida de seleção pelo método genealógico e de população, sendo que as modificações nestes são feitas para adequar as condições de cada programa. Normalmente, a pressão de seleção inicia-se na geração $F_{2}$ para caracteres de alta herdabilidade como tipo de grão, ciclo e porte de planta.

Com o estreitamento da base genética, tanto nas cultivares irrigadas (Rangel et al., 1996) como nas de sequeiro 
(Montalván et al., 1998), o CNPAF tem adotado também a metodologia de seleção recorrente, objetivando explorar melhor a variabilidade para a ampliação da base genética, tanto para as cultivares de sequeiro (Moraes et al.,1997) como para as de irrigado (Rangel \& Neves, 1997).

Além das metodologias convencionais utilizadas no melhoramento do arroz, atualmente são disponiveis outras técnicas para geração de variabilidade, como as técnicas de mutação induzida, variação somaclonal e engenharia genética que possibilita a transferência direta de genes de interesses específicos.

A técnica de mutação induzida utilizada no mundo tem proporcionado o desenvolvimento de grande número de cultivares de arroz (Maluszynski et al., 1995). No Brasil, a utilização da mutação induzida tem sido restrita, porém, em trabalhos básicos realizados por Ando et al. (1980) e Montalvãn \& Ando (1998), evidenciaram-se eficiência desta metodologia para geração de variabilidade em genótipos brasileiros.

A variação somaclonal também tem demonstrado grande potencial para geração de variantes de interesse agronômico. Já no início desta década, Zongxiu et al. (1991) relacionaram 36 cultivares de arroz com características qualitativas e quantitativas de interesse, obtidas por variação somaclonal. No Brasil, esta técnica tem grande potencialidade, uma vez que a maioria das instituições que trabalham com arroz, dispõe de laboratórios para cultivo in vitro. A obtenção de um variante da cultivar IAC $47 \mathrm{com}$ moderada tolerância a brusone (Araújo et al., 1997) ilustra a potencialidade desta técnica para os materiais brasileiros. 


\subsection{Utilização e potencialidades do cultivo in vitro no melhoramento}

O cultivo in vitro explora a totipotencia das células individuais ou de tecidos para regenerar indivíduos em meio de cultura contendo hormônios reguladores de crescimento e outros componentes necessários. Esta técnica tem sido largamente utilizada para propagação clonal massal de espécies de propagação vegetativa, como: banana, morango, citros, entre outras, inclusive podendo proporcionar a limpeza de patógeno quando se faz utilização de meristema (Mantell et al.,1994). No melhoramento de plantas, esta técnica tem sido aplicada em várias etapas, seja como técnica complementar ou como alternativa direta para o desenvolvimento de novas cultivares (Ferreira et al., 1998).

Tais aplicações variam de acordo com as características biológicas das espécies e a estratégia a ser empregada na solução de problemas, podendo ser aplicada, por exemplo, na conservação de germoplasma, para o aumento de variabilidade e para acelerar etapas de programas de melhoramento.

A conservação de germoplasma in vitro é feita principalmente para espécies de propagação vegetativa. Além da conservação, o cultivo facilita o intercâmbio de genótipos entre as Instituições em condições assépticas (Ferreira et al., 1998).

Com a finalidade de gerar variabilidade para 0 melhoramento genético de plantas, esta técnica tem sido aplicada na introgressão de genes de interesse de espécies do mesmo gênero ou até mesmo na intergenérica quebrando a barreira de incompatibilidade, na obtenção de transformantes via engenharia genética. 
Para a quebra de barreiras genéticas, as aplicações mais comuns do cultivo in vitro são: polinização in vitro para superar as barreiras pré-zigóticas; cultura de embrião para superar as barreiras pós-zigóticas; fusão de protoplastos tanto para superar barreiras pré e pós-zigóticas, objetivando a regeneração de plantas cíbridas (Ferreira et al. 1998). No caso de hibridação entre espécies de diferentes ploidias, a obtenção de di-haplóides e/ou haplóide através do cultivo in vitro pode favorecer a manipulação de cromossomos nas recombinações interespecíficas.

Para as técnicas de engenharia genética, o cultivo in vitro, torna favorável a obtenção de indivíduos transformados. Pois a transformação de células individualizadas possibilita a regeneração de plantas não quiméricas (Mantell et al.,1994). Esta é a razão pela qual a indução de mutação em suspensão celular favorece a seleção de mutantes sólidos (Tulmann Neto et al., 1998). O cultivo in vitro pode ainda gerar variabilidade por variação somaclonal.

Com a finalidade de aceleração de programas de melhoramento, o cultivo in vitro pode ser usado para obter a germinação de sementes ou cultura de frutos, na clonagem de genótipos para avaliações, e na cultura de anteras ou micrósporos de populações segregantes, objetivando plantas haplóides, para utilização posterior na obtenção di-haplóides. Esta prática possibilita atingir rapidamente a homozigose dos genótipos superiores para serem selecionados e testados em ensaios de competição (Ferreira et al., 1998). A obtenção rápida da homozigose proporciona economia de tempo e recursos.

Uma outra aplicação importante, embora limitada, é a seleção in vitro, onde é adicionado toxina do patógeno ou faz-se simulação de determinada condição de estresse no meio quanto a 
minerais, de maneira que seja possibilitada a regeneração de plantas, apenas de células resistentes. Vale ressaltar que, além da aplicação direta com objetivo de geração de variabilidade, a maioria das aplicações mencionadas pode gerar variantes com caracteristicas que possam ser utilizadas no melhoramento de plantas.

\subsection{Variação somaclonal}

\subsubsection{Causas e base genética da variação somaclonal}

A passagem de células e tecidos vegetais pela fase de calo, durante o cultivo in vitro, pode causar alterações no genoma da planta, envolvendo inclusive caracteristicas qualitativas e quantitativas. Tais alterações podem ser decorrentes de mutações gênicas simples ou alteração tanto no número quanto na estrutura do cromossomo ou ainda mutação no DNA das organelas citoplasmáticas (D'Amato, 1977; Larkin \& Scowcroft, 1981; Scowcroft et al., 1985; D'Amato, 1985; Lee \& Phillips, 1988; Silvarolla, 1992). O termo variação somaclonal foi utilizado primeiramente por Larkin \& Scowcroft (1981), como designação aos variantes obtidos em decorrência do cultivo in vitro.

Além das alterações de natureza genética, o cultivo in vitro também pode gerar variações fenotípicas não herdáveis decorrentes dos efeitos fisiológicos do meio de cultura, denominadas de alterações epigenéticas (Meins Jr., 1983; Evans \& Sharp, 1986).

Apesar de variantes surgidos em cultura de tecido estarem sempre associados aos efeitos do cultivo in vitro, eles podem também ser provenientes de mutações pré-existentes no 
explante. Segundo Edallo et al. (1981), D'Amato (1985) e Brown et al. (1991), os calos em cultura podem apresentar mosaicismo genético de células tanto proveniente de mutações do explante como originado do cultivo in vitro. A obtenção e detecção de plantas apresentando tais alterações genéticas dependem da capacidade de sobrevivência e proliferação das células presentes no mosaico (Armstrong et al., 1983; Benzion et al., 1986).

Segundo Sybenga (1992), as células livres ou calos são menos estáveis que os tecidos ou órgãos diferenciados, portanto as irregularidades mitóticas são mais frequentes in vitro do que em organismos intactos. Além disso, tais alterações têm sido atribuídas às condições artificiais intrínsecas ao meio de cultivo tais como: tempo de cultivo, intervalos de subcultura e os componentes do meio. Especialmente, os hormônios reguladores de crescimento podem comprometer a integridade do material genético, resultando em numerosas mudanças genômicas das células cultivadas in vitro (Peschke \& Phillips,1992; Silvarolla, 1992; Phillips et al., 1994). Deve-se considerar ainda que o meio artificial suporta mais células alteradas geneticamente do que o organismo, e estas acabam fazendo parte do total de variantes. $\mathrm{Na}$ maioria dos casos, é provável que ocorra interações entre os fatores estressantes e o genótipo em questão. Por exemplo, em batata, Fish \& Karp (1986) verificaram que, em plantas regeneradas a partir de protoplastos, a diferença de ploidia do explante influencia na frequência da variação, onde genótipos poliplóides apresentaram maiores taxas de variação cromossômica que os diplóides.

As modificações genéticas que explicam a variação somaclonal podem ser ocasionadas por: aberrações cromossômicas, mutações de ponto, ativação de elementos 
transponiveis, amplificação gênica, alterações no DNA das organelas, mudanças na quantidade de DNA total e no número de cópias do DNA repetitivo (Phillips et al., 1990). Portanto, os mecanismos que causam eventos mutacionais in vitro são os mesmos que ocorrem na natureza, porém, em sistemas artificiais estes eventos ocorrem com maior frequência.

\subsubsection{Alterações no número e estrutura dos cromossomos}

As alterações cromossômicas provocadas pelo cultivo in vitro são, principalmente númericas, tanto euploidia como aneuploidia, mas também podem ocorrer alterações estruturais. As alterações cromossômicas numéricas podem resultar de endopoliploidização ou de fusão nuclear, e os aneuplóides podem ser causados por não disjunção e atraso cromossômico ou aberrações nas fibras do fuso. Entre as aberrações estruturais, tem-se as duplicações, deleções, inversões e translocações. Elas são consequências de quebras cromossômicas, com ou sem fusão de extremidades cromossômicas quebradas (Bayliss, 1980; D'Amato, 1985; Phillips et al., 1994).

Muitos estudos têm mostrado que mudanças na estrutura de cromossomos podem ocorrer durante o cultivo in vitro. Análises citológicas de plantas regeneradas têm evidenciado a incidência de quebras cromossômicas e suas consequências, e estas têm sido frequentemente associadas a regiões de heterocromatina (Phillips et al., 1990).

Baseado no fato de que as quebras cromossômicas frequentemente ocorriam entre regiões de heterocromatina e no centrômero, Phillips et al. (1988) propuseram uma hipótese de que deveria ocorrer um atraso maior que o usual na replicação da 
heterocromatina in vitro, resultando na formação de pontes e consequentemente, quebras cromossômicas.

Dentro deste contexto, Santos (1995) e Fluminhan et al. (1996) analisaram a instabilidade mitótica em cultura de calos embriogênicos de milho, observaram fragmentos e pontes na anáfase e telófase, bem como eventos de atraso na separação de cromátides. Através da utilização da metodologia de bandamento-C foi observada a ocorrência de atraso na separação de cromátides ao nível de knobs heterocromáticos, bem como pontes envolvendo cromossomos e knobs, confirmando assim a hipótese proposta por Phillips et al. (1988). A análise de metáfase e anáfase coradas pelo bandamento-C forneceu evidência de quebra-fusão-ponte in vitro, envolvendo o cromossomo 7 da linhagem estudada.

O ciclo de quebra-fusão-ponte foi inicialmente descrito por McClintock (1941) em milho. Durante a intérfase, as extremidades de quebra soldam-se, e na segregação das cromátides ocorre a formação de uma ponte, seguida de nova quebra em qualquer região, originando novamente um cromossomo quebrado que reiniciará o ciclo ou sofrerá cicatrização, permanecendo estruturalmente alterado. Este ciclo pode ocorrer várias vezes ou como evento único no início da cultura. Acredita-se que a ocorrência de quebras em um cromossomo pode levar à indução de quebras adicionais em outros cromossomos não envolvidos no ciclo original (Lee \& Phillips, 1987).

Joachimiak et al. (1993), estudando cariótipos de células de calos em culturas de longa duração em Allium, verificaram anormalidades como: formação de micronúcleos e megacromossomos ou cromossomos gigantes. Verificou-se que estas anormalidades aumentaram conforme o tempo do cultivo in vitro. 
Kunitake et al. (1998) observaram variações na ploidia de Asparagus officinalis oriunda da cultura de calos e que essas variações cromossômicas aumentavam conforme o número de subcultivos e tempo de cultura. Foram observadas plantas haplóides e tetraplóides geradas pela cultura in vitro sendo que cerca de $80 \%$ das plântulas possuíam caracteres afetados. Um caráter bastante modificado foi altura das plantas, havendo um grande número de plantas anãs.

Com relação ao tempo de cultura, Fluminhan $\&$ Kameya (1996) também observaram aumento na quantidade de pontes a medida que o tempo da cultura foi aumentando.

\subsubsection{Hipo e hipermetilação do DNA}

A metilação do DNA está relacionada com a regulação da expressão gênica nos eucariontes. Normalmente, o padrão de expressão gênica é alterado pela adição de grupamentos metil em nucleotídeos, principalmente em citosinas seguidas de guaninas, presentes nas sequências do DNA e, por isso, a metilação tem sido sugerida como um mecanismo de controle epigenético (Holliday, 1987). Tal modificação é um processo pós-replicativo, estável e herdável, no qual ocorre a transferência do grupamento metil da Sadenosilmetionina para a posição 6 da adenina, ou para a posição 5 da citosina.

A porcentagem de citosinas metiladas varia nos eucariontes. Em vegetais superiores, cerca de $30 \%$ de todas as citosinas apresentam o grupamento metil em ambos os sítios $C G$ e CNG. A função principal da metilação ocorre na inativação do DNA não transcrito, impedindo-o de interagir com proteínas regulatórias. Atualmente, sabe-se que a metilação está associada a inibição da 
transcrição pela associação de proteinas especificas tais como: MeCP1 e MeCP2 que se ligam ao DNA metilado (Lewin, 1994).

Em cultura de tecidos, há relatos de que ocorre um incremento das taxas de metilação (hipermetilação) ou sua atenuação (hipometilação). Como consequência, ocorrem alterações nos processos de regulação da atividade gênica, hiper ou hipoativação de elementos transponíveis e modificações na estrutura da cromatina (Bretell \& Dennis, 1991; Loschiavo et al., 1989).

Durante a micropagação e indução de calos de Vitis vinifera, Harding et al. (1996) observaram mudanças na metilação do DNA, analisando sequências de rDNA que foram metiladas durante o cultivo in vitro. Usando as enzimas de restrição Mspl/Hpall, foram analisadas plantas, em casa de vegetação, contendo $7,7 \%$ de citosinas metiladas. Na fase inicial da cultura in vitro, esta taxa aumentou para $64,5 \%$ e na fase final (quarto subcultivo) aumentou ainda mais, atingindo $72,5 \%$. Os autores sugerem que, com o aumento do tempo de cultivo in vitro, ocorre acréscimo da metilação, podendo assim influência no processo de desenvolvimento e manutenção da totipotência de células no cultivo in vitro.

\subsubsection{Ativação de elementos transponíveis}

Os elementos de transposição são sequências genéticas móveis dispersas no genoma de diversos organismos (McClintock, 1984). Segundo Kunze et al. (1997), a distribuição de tais elementos é bastante ampla na escala evolutiva, tendo papel fundamental na geração de variabilidade. Inicialmente os elementos foram caracterizados devido ao aparecimento de 
mutações instáveis que estes causam quando se inserem e se excisam de um gene (McClintock, 1984; Kunze et al., 1997).

Atualmente, os elementos genéticos móveis são divididos em duas classes: retrotransposons, que se movem via um RNA intermediário, e elementos transponiveis, que se movem via DNA, e estas classes se dividem em grupos ou famílias (Kunze et al., 1997).

Ambas as classes possuem elementos autônomos e defectivos. Os elementos autônomos possuem a capacidade de codificar proteínas necessárias para a sua transposição, enquanto elementos defectivos possuem deleções nessas sequências, sendo portanto imóveis. Sua mobilização depende do fornecimento destas proteinas por outros elementos autônomos existentes no genoma (Kunze et al., 1997; Chomet et al., 1987).

Os retrotransposons são os elementos genéticos móveis mais abundantes em plantas. Ao todo, constituem uma fração substancial do genoma das plantas, chegando a ser, muitas vezes, mais de 40\% (Heslop-Harrison et al., 1997). A metilação está relacionada com a regulação da expressão dos elementos genéticos móveis. A atividade dos elementos transponiveis tem sido relacionada com a redução da metilação em sítios específicos dentro destes elementos (Chomet et al., 1987; Fedoroff \& Chandler, 1994; Fedoroff, 1989; Scortecci et al.,1997), assim como a hipermetilação tem causado o silenciamento desses elementos (Fedoroff et al., 1995).

McClintock (1984) atribuiu ao estresse genômico os estímulos endógenos e exógenos que permitem a ativação de elementos transponiveis. Uma hipótese é que o estresse genômico induz um dano no DNA causando rápida atividade de reparo após 
desmetilação, possibilitando a reativação transcricional de elementos transponiveis silenciosos (Kunze et al., 1997).

A propagação de plantas por cultura de tecidos tem induzido uma variedade de mudanças epigenéticas. A alteração no padrão de metilação tem sido proposta para explicar essas mudanças e um possível mecanismo envolvido na indução de variação somaclonal é a ativação de elementos transponíveis. A ativação dos elementos Ac/Ds e Spm foi estudada por Peschke et al. (1987) e Peschke et al. (1991). Retrotransposons foram recentemente clonados com o auxílio da PCR, usando como primers sequências conservadas da transcriptase reversa e tem sido verificada sua ativação durante o cultivo in vitro. Foi verificado que os retrotranposons foram ativados na cultura de protoplastos de fumo e que o número de cópias do elemento Tto1 aumentou cerca de dez vezes (Hirochika, 1993). Estes retroelementos também têm sido observados na cultura de tecidos de arroz, na qual o número de cópias aumentou conforme o tempo de cultura, chegando a cerca de 30 vezes (Hirochika et al., 1996).

Devido à forma através da qual eles se transpõem, os elementos transponiveis causam mutações instáveis, enquanto os retrotransposons induzem mutações estáveis na cultura de tecidos (Hirochika, 1995; Hirochika et al., 1996).

\subsubsection{Modificações no DNA citoplasmático}

Os genomas da mitocôndria (mtDNA) e do cloroplasto (cpDNA) distinguem-se do genoma nuclear por serem moléculas circulares que existem em várias cópias dentro dessas organelas. A maioria do genoma mitocondrial de plantas existe sob a forma de uma população heterogênea de moléculas circulares. 
Recombinações levam à formação de uma subpopulação de moléculas circulares (Palmer \& Shields, 1984). Análises moleculares indicam que a integridade do genoma mitocondrial pode ser facilmente rompida durante a cultura de tecidos. Rearranjos têm sido observados em suspensão celular de Vicia faba, em suspensão celular de arroz, em cultura de calos de beterraba, na embriogênese somática de trigo e em híbridos somáticos de espécies de Brassica (Clotier \& Landry, 1994).

Rode et al. (1989) analisaram plantas de trigo regeneradas a partir de embriogênese somática, através de RFLP, usando como sonda um segmento de mtDNA, e encontraram diferenças em relação às plantas controle que não passaram pela cultura de tecidos. Os autores observaram também, que a cultura de longa duração produziu maior variabilidade no DNA mitocondrial do que a cultura por tempo reduzido.

Breiman \& Shimron-Abarbanell (1991) analisaram plantas regeneradas de calos de Hordeum marinum com duas enzimas de restrição, usando como sonda sequências codantes e não codantes de DNA genômico e mitocondrial. Foram analisadas 50 plantas regeneradas as quais mostraram polimorfismo quando hibridizadas com sondas de mtDNA. Estes autores observaram que a cultura de tecidos pode induzir modificações no DNA mitocondrial de plantas regeneradas de calos e suspensões celulares.

Muitos estudos indicam que o tempo da cultura in vitro é a maior causa da instabilidade em DNA mitocondrial. Assim, em suspensões celulares de arroz, foram observadas modificações nas sequências, sugerindo que houve um intenso rearranjo no mtDNA (Saleh et al., 1990).

O genoma cloroplastidial é simples e consiste em somente uma molécula de DNA circular com pouco DNA repetitivo. 
Menor número de variações foi observado nas moléculas de cpDNA durante o cultivo de arroz em suspensão celular (Chowdhury et al., 1988). Isto pode ser consequência da letalidade às células, que não suportam qualquer modificação nesse genoma (Brears et al., 1989).

Segundo Brown (1989) e Phillips et al. (1988), várias mudanças gênicas qualitativas e quantitativas em plantas regeneradas e suas respectivas progênies podem estar relacionadas com a metilação do DNA. A transcrição do elemento Ac ocorre com a desmetilação da região promotora do mesmo (Schwartz, 1989). A ativação do elemento Ac ocorre em condições naturais (Johns, 1991) e em plantas provenientes do cultivo in vitro (Brettel \& Dennis, 1991; Kaepler \& Phillips, 1993).

\subsection{Aplicação da variação somaclonal no melhoramento de plantas}

Como já mencionado, a variabilidade genética é de fundamental importância quando se objetiva a seleção de genótipos transgressivos nos programas de melhoramento de plantas. Neste contexto, a variação somaclonal constitui uma fonte de variabilidade importante, pois pode gerar variantes estáveis, tanto para caracteres qualitativos como quantitativos (Meins Jr., 1983; Peschke \& Phillips, 1992). Porém, as manifestações fenotípicas são decorrentes de mudanças genéticas envolvendo desde pequenas alterações em genes nucleares e citoplasmáticos às grandes alterações no número e estrutura cromossômica. Como as espécies cultivadas já acumulam em seus genomas uma alta frequência de genes favoráveis, as grandes alterações que envolvem número ou grandes porções de cromossomo normalmente 
causam perturbações a organização genômica existente, originando caracteristicas desfavoráveis ou deletérias. Além disso, normalmente a variabilidade desejada refere-se a um ou poucos caracteres, governados por gene ou genes especificos. As poliploidias, entre outras manifestações, ocasionam irregularidades meióticas que resultam em altas taxas de esterilidade, comprometendo a produção de grãos. Portanto, alterações cromossômicas têm sido menos úteis para seleção de caracteres de interesse no melhoramento que as alterações gênicas, as quais podem ocorrer apenas quanto ao caráter em que se deseja melhorar.

Apesar das evidências de que as condições intrínsecas ao cultivo in vitro, tais como tempo de cultivo, intervalo de subcultivo e fitormônios usados, interferem na taxa de variação somaclonal, em relação às mudanças hereditárias, o evento é de natureza aleatória. Portanto, a probabilidade de se obter variação para um determinado caráter desejado é proporcional ao número de plantas regeneradas e também à herança do caráter em questão. Naturalmente, quando se tem por objetivo a seleção de característica governada por muitos genes, deve-se trabalhar com população maior, objetivando aumentar a probabilidades de obter os genótipos com a combinação gênica desejada. Além disso as avaliações devem ser conduzidas sempre utilizando-se de parâmetros genéticos e estatísticos.

Assim como a variabilidade gerada por outras metodologias, os somaclones, dependendo da potencialidade dos genótipos variantes obtidos, podem ter utilização direta como cultivares ou através da recombinação em programas de melhoramento convencionais (Evans et al., 1984). 
Com a necessidade cada vez maior de se aumentar a variabilidade genética nos programas de melhoramento e o número de espécies estudadas in vitro, a variação somaclonal terá cada vez mais importância como fonte de novos genes de interesse agronômico.

\subsection{Variação somaclonal no melhoramento do arroz}

Em arroz, tem sido identificada a alteração fenotípica em decorrência de variação somaclonal para vários caracteres de interesse agronômico. Já no início desta década, em um trabalho de revisão, Zongxiu et al. (1991) relacionaram 36 cultivares com características de interesse econômico obtidos por esta metodologia. Entre os caracteres melhorados, estão: rendimento e tipo de grão, melhoria no conteúdo proteína, inclusive maior teor de lisina, tolerância a estresses bióticos (causados por vírus, bactérias e fungos), tolerância a estresses abióticos (tais como a seca, salinidade e alumínio), além de precocidade, porte anã e semi-anã e maior produtividade. Ainda com relação a tolerância a seca que é uma característica importante para as cultivares de sequeiro foi obtido por Adkins et al. (1995).

Os exemplos, mencionados pelos autores, tornam evidente que através da variação somaclonal é possivel gerar variabilidade para a maioria das características objetivadas nos programas de melhoramento de arroz, tanto para herança qualitativa quanto qualitativa.

$\mathrm{Na}$ literatura mais recente, tem sido relatada a obtenção de genótipos tanto para os caracteres mencionados como para outros de interesse econômico, no entanto não é feita referência quanto ao uso dos mesmos como cultivar. Isto se deve 
provavelmente ao fato de ocorrer alteração também para caracteres indesejáveis ou ainda porque o genótipo ou a cultivar original não apresenta valor comercial, inviabilizando assim sua utilização direta.

Em progênies de plantas de arroz obtidas de plotoplastos, também tem sido relatada a obtenção de variantes para caracteres tanto qualitativos como quantitativos. A exemplo disso, Yamagishi et al.(1997) identificaram variantes de porte anã, alteração no tamanho e densidade de panícula, além variantes quanto a pigmentação de folha e grão. Ogura et al. (1987) relatam a ocorrência de triploidia e poliploidia ocasionando alta taxa de esterilidade, em progênies de plantas de arroz regeneradas a partir de protoplastos.

Estudando progênies de plantas derivada de protoplastos, em relação a outras não derivadas, Yamagishi et al. (1996) verificaram que as progênies derivadas de protoplastos tiveram maior taxa de poliploidia (33-70\%) em relação às não derivadas de protoplastos. Além das alterações decorrentes da euploidia como esterilidade, também foram obtidos variantes de porte baixo.

Outros somaclones com características importantes para condições de cultivo específicas têm sido relatados na literatura, como por exemplo: tolerância a imersão em água (Adkins et al.,1987; Adkins et al., 1990), adaptabilidade a altitudes elevadas Bertin et al., 1996) e tolerância ao frio (Bertin et al., 1996; Bertin \& Bouharmont, 1997), sendo que no último caso a seleção dos genótipos melhorados foi feita in vitro.

Utilizando a cultivar brasileira IAC 47, Araújo et al. (1997) obtiveram duas progênies que apresentaram resistência parcial à brusone em avaliações feitas na terceira geração. 
No entanto, tais genótipos terão importância apenas como fonte da resistência ao patógeno a ser transferida por hibridação em programas de melhoramento, uma vez que a cultivar original tem tipo de grão longo que é uma característica não almejada para cultivares a serem liberadas para o cultivo. 


\section{MATERIAL E MÉTODOS}

\subsection{Material}

Foram avaliadas as progênies originárias de 20 plantas férteis da cultivar IAC 201 e de 38 plantas férteis da cultivar IAC 165, no total de 58 plantas regeneradas a partir de protoplastos de escutelo de sementes germinadas. O número de plantas regeneradas e de progenies avaliadas se encontra na Tabela 1.

A cultivar IAC 165 foi selecionada do cruzamento entre Dourado Precoce e IAC 1246, sendo liberada para o cultivo pelo Instituto Agronómico de Campinas (IAC) em 1980. Trata-se de uma cultivar de ciclo precoce, porte alto, tipo de grão longo e suscetivel a brusone (CATI, 1996). Esta cultivar continua ainda sendo recomendada para os Estados de São Paulo, Bahia, Espírito Santo e Mato Grosso (EMBRAPA, 1997)

Já a cultivar IAC 201 foi selecionada do cruzamento entre IAC 165 e Labelle, e liberada em 1992 também pelo IAC. Apresenta ciclo precoce e suscetibilidade a brusone e tem porte médio e grão de classe longo-fino (CATI, 1996), que é uma caracteristica desejável transferida da parental americana Labelle. Atualmente, tem sido recomendada para os Estados de São Paulo e Mato Grosso do Sul (EMBRAPA, 1997). 
Apesar das duas cultivares serem consideradas de boa adaptabilidade edafoclimática, as mesmas apresentam características indesejáveis: ambas apresentam sucetibilidade à brusone; a IAC 165 apresenta porte alto e a IAC 201 mostra porte médio, o que torna-as também suscetíveis ao acamamento. Além disso, a IAC 165 tem tipo de grão longo que não alcança os preços obtidos com produto de grão longo-fino como a IAC 201 e da maioria das cultivares irrigadas.

A obtenção de genótipos variantes dessas duas cultivares, que não apresentem estas caracteristicas indesejáveis, representa uma grande perspectiva para o melhoramento do arroz de sequeiro.

O estudo de regeneração das plantas foi realizado em um trabalho desenvolvido em colaboração, entre a Seção de Radiogenética do CENA/USP e o Departamento de Genética ESALQ/USP, e teve por objetivo estudar a regeneração de protoplastos de calos primários. Neste trabalho, foi estabelecida a metodologia de regeneração de plantas a partir de protoplastos para as referidas cultivares (Moura, 1994; Moura et al., 1997).

A obtenção dos calos primários da IAC 201 foi feita em meio N6, suplementado com $2 \mathrm{mg} / \mathrm{l}$ de 2,4-D e 0,5 mg/l de caseína hidrolizada. Para a cultivar IAC 165, foi utilizado o meio B5 suplementado com $2 \mathrm{mg} / \mathrm{l}$ de 2,4-D e $5 \mathrm{mM}$ de L-prolina. Em ambos os meios, utilizou-se $3 \%$ de sucrose, $0,8 \%$ de difco agar e $\mathrm{pH}$ ajustado em 5,8, sendo a cultura incubada de 30 a 40 dias.

Após o isolamento, os protoplastos foram induzidos à divisão em meio R2 (Ohira et al., 1973) com as seguintes modificações: $1 \mathrm{mg} / \mathrm{l}$ de ácido nicotínico, $2 \mathrm{mg} / \mathrm{l}$ de tiamina, $1 \mathrm{mg} / \mathrm{l}$ de piridoxina, $100 \mathrm{mg} / \mathrm{l}$ de inositol, $1 \mathrm{mg} / \mathrm{l}$ de 2,4-D, 0,4 $\mathrm{M}$ maltose e $0,6 \%$ de agarose com pH ajustado em 5,6 antes da esterilização. 
A regeneração das plantas foi feita em três diferentes meios de cultura semi-sólidos ( $M S, N 6$ e R2), suplementados com diferentes concentrações dos hormônios NAA, KIN e BAP preparados em $6 \%$ de agarose. Após 50 a 60 dias do início do cultivo dos protoplastos isolados, foram obtidas as plantas regeneradas que em seguida foram conduzidas em solução nutritiva e, posteriormente em vasos com terra preparada, até a produção de sementes (Moura et al., 1997).

Todas as plantas regeneradas, de cada cultivar, foram agrupadas e utilizadas no presente trabalho, constituindo a geração $R_{1}$.

As sementes obtidas das plantas regeneradas $\left(R_{1}\right)$ de ambas as cultivares foram utilizadas para constituir dois experimentos distintos conduzidos por dois anos consecutivos.

As sementes obtidas das plantas regeneradas $\left(R_{1}\right)$ foram semeadas em progênies, no máximo 100 por planta, no campo experimental do Departamento de Genética, ESALQ/USP, durante o ano agrícola de 1995/96, objetivando principalmente a multiplicação de sementes e avanço de geração. Nas plantas da segunda geração $\left(R_{2}\right)$, foram amostradas sementes para constituir os experimentos da terceira geração $\left(R_{3}\right)$, conduzidos no ano agrícola de 1996/97. Na geração $R_{3}$, avaliou-se as principais características agronômicas e amostrou-se sementes de todas as progênies para constituir o experimento da quarta geração $\left(R_{4}\right)$, conduzido no ano agrícola de 1997/98. Foram incluídas nestes experimentos $\left(R_{4}\right)$ as linhagens selecionadas no ano anterior, objetivando avaliar se houve manutenção dos caracteres variantes observados ou surgimento de novos variantes. 
Tabela 1. Relação do número de plantas regeneradas e conduzidas da primeira geração $\left(R_{1}\right)$ à quarta geração $\left(R_{4}\right)$.

\begin{tabular}{lccccc}
\hline $\begin{array}{c}\text { Cultivar } \\
\text { original }\end{array}$ & $\begin{array}{c}\text { Número de } \\
\text { plantas férteis } \\
\text { regeneradas } \\
\left(R_{1}\right)\end{array}$ & $\begin{array}{c}\text { Número } \\
\text { de } \\
\text { sementes } \\
\text { obtidas } \\
\left(R_{1}\right)\end{array}$ & $\begin{array}{c}\text { Número de } \\
\text { plantas } \\
\text { conduzidas } \\
\left(R_{2}\right)\end{array}$ & $\begin{array}{c}\text { Número } \\
\text { de } \\
\text { progênies } \\
\left(R_{3}\right)\end{array}$ & $\begin{array}{c}\text { Número } \\
\text { de } \\
\text { progênies } \\
\left(R_{4}\right)\end{array}$ \\
\hline IAC 201 & 20 & 6430 & 729 & 729 & 729 \\
IAC 165 & 38 & 3609 & 270 & 270 & 270 \\
\hline
\end{tabular}

As cultivares IAC 165, IAC 201 e Guarani foram também utilizados nos experimentos da terceira e quarta gerações $\left(R_{3}\right.$ e $\left.R_{4}\right)$, como testemunha.

\subsection{Condução dos experimentos}

Os experimentos foram instalados na área experimental do Departamento de Genética da ESALQ/USP em Piracicaba, SP. Foram conduzidos nos anos agrícolas de 1996/97 e 1997/98, sendo as sementes semeadas em sulcos na segunda quinzena de novembro e primeira de dezembro, respectivamente.

$\mathrm{Na}$ ocasião da semeadura, foi feita adubação de 150 $\mathrm{Kg} / \mathrm{ha}$ da fórmula 4-14-8 e, em torno de 40 dias após a emergência, realizou-se adubação de cobertura com $30 \mathrm{~kg}$ de nitrogênio por hectare. Durante a condução desses experimentos, procederam-se os tratos culturais de rotina, além de irrigação suplementar por aspersão.

As progênies de cada cultivar constituíram experimentos distintos no delineamento de blocos aumentados 
sendo que as progênies das plantas regeneradas da cultivar IAC 165 constituíram um experimento com 810 fileiras subdivididas em 27 blocos de 30 linhas nos anos agrícolas de 1996/97 e 1997/98. Já as progênies das plantas regeneradas da cultivar IAC 201 constituíram, por sua vez, um experimento com 300 fileiras subdivididas em 10 blocos de 30 linhas nos anos agrícola 1996/97 e 1997/98. Em cada bloco, foram sorteados as linhagens denominadas neste delineamento de tratamentos regulares e as testemunhas denominadas de tratamentos comuns (IAC 165, IAC 201 e Guarani).

As parcelas experimentais úteis de cada tratamento foram constituidas de uma linha de um metro, com densidade de 75 sementes por metro, espaçadas a $0,50 \mathrm{~m}$ entre linhas.

\subsection{Obtenção dos dados}

As avaliações foram feitas quanto às seguintes características: número de dias até o florescimento, altura de planta, comprimento de panícula, número de espiguetas por panícula, porcentagem de espiguetas granadas por panícula, produtividade e peso de 1000 grãos. Dos dois últimos caracteres, foram tomados dados apenas nos experimentos conduzidos no ano agrícola de 1997/98.

\subsection{Caracteristicas avaliadas}

\subsubsection{Número de dias até o florescimento (CICLO)}

Para determinação deste caráter, foi protocolado o dia em que cada parcela apresentou visualmente cerca de $50 \%$ das 
inflorecências emitidas. O número de dias até o florescimento foi calculado a partir do dia da emergência das plântulas, até a data em que foi protocolado o florescimento, conforme Azzini et al (1995).

\subsubsection{Altura de planta (AP)}

A altura de planta foi tomada em centímetros, com o emprego de régua de $1,5 \mathrm{~m}$ de comprimento com precisão de $1 \mathrm{~cm}$, a qual foi apoiada no solo junto à planta, sendo seu comprimento medido da base da planta até a extremidade da panícula do colmo mais alto conforme Azzini et al, (1995).

Para cada parcela, foram medidas dez plantas diferentes em cada linha, tomadas ao acaso na ocasião da maturação, conforme Soares et al. (1993). A média dos dez valores passou a representar cada parcela.

\subsubsection{Comprimento de panícula (CP)}

O comprimento de panícula foi tomado do primeiro nó até a extremidade da panícula conforme EMBRAPA (1977). Foram medidas 15 panículas, colhidas ao acaso em cada parcela. A média obtida entre os valores observados foi utilizada para representar cada parcela.

\subsubsection{Número de espiguetas por panicula (NEP)}

Foram contadas todas as espiguetas granadas e não granadas, de todas as 15 panículas colhidas em cada parcela 
para avaliação do comprimento. A média dos valores obtidos de todas elas foi utilizada para representar a parcela.

\subsubsection{Fertilidade (FER)}

Este caráter foi avaliado em porcentagem, considerando as mesmas panículas avaliadas na determinação do número de espiguetas por panícula. Para tanto, todas foram debulhadas e as espiguetas separadas manualmente em dois grupos: granadas e estéreis. Foram consideradas estéreis as espiguetas totalmente chochas. Após a contagem do número de espiguetas granadas e estéreis, obteve-se o valor percentual de espiguetas granadas por panícula. A média percentual obtida entre 15 panículas passou a representar a parcela nas análises estatisticas.

\subsubsection{Produção (PROD)}

A produção foi representada pelo peso total em gramas de todas as espiguetas granadas obtidas por parcela, incluindo as utilizadas em 3.4.5.

\subsubsection{Peso de 1.000 grãos (PMG)}

Este caráter foi avaliado através da obtenção de oito amostras de 100 sementes por parcela com umidade de $13 \%$, pesadas em balança de precisão de $0,01 \mathrm{~g}$. Quando o coeficiente de variação das oito amostras não ultrapassou $6 \%$, multiplicou-se 0 
resultado médio do peso das amostras por 10 para obter o peso de 1.000 grãos para cada parcela, conforme as regras para análise de sementes (BRASIL, 1992).

\subsection{Análises estatísticas}

O modelo matemático para o delineamento de blocos aumentados é:

$$
Y_{i j}=\mu+t_{i^{\prime}}+t_{(j) i}+b_{j}+e_{i j}
$$

onde:

$Y_{i j}$ é o valor observado na parcela do bloco j que recebeu o tratamento comum i' ou o tratamento regular i dentro do bloco j;

$\mu$ é o efeito fixo da média geral;

$t_{i^{\prime}}$ é o efeito fixo do tratamento comum i';

$t_{(j) i}$ é o efeito aleatório do tratamento regular i dentro do bloco j;

$b_{j}$ é o efeito aleatório do bloco j;

$e_{i j}$ é o efeito aleatório do erro experimental associado à parcela do bloco j que recebeu o tratamento comum i' ou o tratamento regular i dentro do bloco j, admitindo-se que os erros são independentes e normalmente distribuídos com média zero e variância $\sigma^{2}$. 
O delineamento assumiu $k_{j}$ número de parcelas por bloco, $p$ número de parcelas em cada bloco que contém os tratamentos comuns.

O esquema da análise de variância para 0 delineamento de blocos aumentados é demonstrado na Tabela 2.

Tabela 2. Esquema da análise de variância em blocos aumentados utilizando o erro intrabloco

\begin{tabular}{llll}
\hline Causas de Variação & G.L. & QM & Teste F \\
\hline Bloco & $(\mathrm{b}-1)$ & ----- & \\
Tratamento ajust. & $(p+t-1)$ & $\mathrm{QM}_{2}$ & $\mathrm{QM}_{2} / \mathrm{QM}_{1}$ \\
Erro intrabloco & $(\mathrm{t}-1)(\mathrm{b}-1)$ & $\mathrm{QM}_{1}$ & \\
\hline Total & $(\mathrm{N}-1)$ & & \\
\hline
\end{tabular}

onde:

b: número de bloco;

t: número de testemunhas (tratamentos comuns)

$\mathrm{p}$ : número de progênies (tratamentos regulares)

$\mathrm{N}$ : número total de parcelas.

O erro intrabloco obtido na referida análise só permite comparações entre tratamentos regulares testados no mesmo bloco. A comparação entre progênies situadas em diferentes blocos deve ser feita com um erro $\sigma_{\mathrm{e}^{\prime}}^{2}$, utilizando-se para isso as médias ajustadas dos tratamentos regulares. Entretanto, para evitar o uso de dois erros diferentes, procurou-se estimar o erro efetivo médio $\sigma_{\mathrm{ef}}^{2}$. 
A partir da análise intrablocos, estimou-se as variâncias entre tratamentos regulares do mesmo bloco e de blocos diferentes, e com estes valores, calculou-se a variância do erro efetivo médio. Ferreira, citado por Barbosa (1996), desenvolveu um testador o qual foi denominado de erro efetivo, que é obtido pela seguinte fórmula:

$\mathrm{QME}_{\mathrm{e}}=\left(1+\frac{1}{r+t-1}+\frac{r}{t(r+t-1)}+\frac{r \sum_{k=1}^{b} n_{k}^{2}}{t^{2}(r+t-1)}-\frac{2 \sum_{k=1}^{b} n_{k}^{2}}{t n(r+t-1)}+\frac{b \sum_{k=1}^{b} n_{k}^{2}}{n^{2}(n+t-1)}\right) Q M E_{t}$ onde:

$Q_{\mathrm{Q}}$ : quadrado médio do erro efetivo;

r: número de tratamentos regulares;

t: número de tratamentos comuns;

b: número de blocos;

$\mathrm{n}_{\mathrm{k}}$ : número de tratamentos (regulares + comuns) no bloco;

$n$ : número total de parcela $\left(n=\sum_{k=1}^{b} n_{k}\right)$;

QME $E_{t}$ quadrado médio do erro da análise intrabloco.

Posteriormente, calculou-se a variância entre as médias ajustadas, obtidas a partir da análise utilizando o erro intrablocos. Desta variância, constituiu-se o quadrado médio de tratamento, sendo que nesta análise, utilizou-se o erro efetivo. Os componentes da variância foram estimados como se fosse um delineamento inteiramente casualizado com uma repetição. A variância genética $\left(\sigma_{\mathrm{g}}^{2}\right)$ foi obtida pela seguinte relação: 


$$
\sigma_{g}^{2}=Q M T / Q M E
$$

onde:

QMT: Quadrado médio dos tratamentos, obtido a partir das médias ajustados;

QME: Quadrado médio do erro efetivo

\subsection{Estimativas dos parâmetros genéticos}

\subsubsection{Herdabilidade}

Para cada caraterística, foi determinado o coeficiente médio de herdabilidade para as progênies, conforme a seguinte fórmula:

$$
h^{2}=\frac{\sigma_{g}^{2}}{\sigma_{f}^{2}}
$$

onde:

$\mathrm{h}^{2}$ : herdabilidade do caráter, considerando a média da progênie;

$\sigma_{\mathrm{g}}^{2}$ : variância genotípica entre médias de progênies;

$\sigma_{\bar{F}}^{2}$ : variância fenotípica entre progênies, com base na média entre parcelas; 


\subsubsection{Coeficiente b}

Para cada caráter, foram determinados o coeficiente de variação genética $(\mathrm{CVg})$, o coeficiente de variação experimental $(C \vee e)$ e a relação entre eles (b).

$$
b=C V g / C V e
$$

O coeficiente de variação genética foi estimado através seguinte fórmula:

$$
C V g=\left(\frac{\hat{\sigma}_{g}}{\bar{X}}\right) \cdot 100
$$

O coeficiente de variação experimental, foi obtido pela seguinte fórmula:

$$
C V e=\left(\frac{\hat{\sigma}_{e}}{\bar{x}}\right) \cdot 100
$$

onde:

$\bar{X}:$ média do caráter;

$\hat{\sigma}_{g}:$ desvio padrão genotípico;

$\hat{\sigma}_{e}$ :desvio padrão do erro experimental.

\subsection{Critério de agrupamento de médias de SCOTT-KNOTT}

Sendo detectadas diferenças significativas entre os genótipos para os caracteres através do teste " $F$ ", aplicou-se 0 
critério de agrupamento de médias de SCOTT-KNOTT (1974). Tal critério é indicado para detectar diferenças entre grupos de médias de tratamentos para delineamentos balanceados, em especial, nos casos em que se compara grande número de genótipos (Pacova, 1992). O método consiste essencialmente no processo hierárquico ou ramificado, no qual $\mathbf{n}$ médias de tratamentos são divididas em dois grandes grupos, sendo em seguida, cada um dos grupos subdivididos em subgrupos e, assim por diante, caracterizando um processo contínuo de divisões, pelo qual, cada subgrupo contém padrões de similaridade mútua do conjunto de dados. O processo de subdivisões termina quando a diferença entre dois subgrupos não for mais significativa. 


\section{RESULTADOS E DISCUSSÃO}

\subsection{Análise estatística}

Antes de proceder a discussão dos resultados é conveniente justificar $\circ$ porque optou-se pela utilização do delineamento em blocos aumentados. Segundo Bearzoti (1994), o emprego desse delineamento é adequado para situações em que se dispõe de número reduzido de sementes, e que haja necessidade de avaliar um grande número de genótipos como ocorre comumente, nas fases iniciais dos programas de melhoramento. Uma outra característica deste delineamento refere-se ao fato de não se faz uso de repetições, o que possibilita consequentemente a avaliação de um número maior de tratamentos em relação aos delineamentos convencionais.

Segundo Tavares (1998), esse delineamento mostrouse eficiente quando utilizado nas etapas iniciais dos programas de melhoramento de cenoura, por permitir a avaliação de um número maior de progênies ou famílias com considerável redução de recursos financeiros e de mão de obra.

Como neste trabalho foi obtido um grande número de progênies das plantas $R_{2}$, principalmente da cultivar IAC 165 , fezse opção por este delineamento tentando-se obter maior representatividade de amostragem nas progênies da referida geração. 
Para a análise estatística, considerou-se em experimentos distintos as progênies das gerações $R_{3}$ e $R_{4}$ das duas cultivares de arroz: IAC 201 (experimento 1) e IAC 165 (experimento 2) em dois anos agricolas de 1996/97 e 1997/98.

Os resultados das análises de variância de cada um dos experimentos, para cada um dos anos agrícolas, são apresentados nas Tabelas 3 a 6 , sendo obtidos pelo Software MAPGEN elaborado por Ferreira \& Zambalde (1997).

Pela Tabela 3 que refere-se às progênies da cultivar IAC 201, avaliadas no ano agrícola de 1997/98, observa-se que não houve diferença significativa $(P \geq 0,05)$ para os caracteres considerados na análise. Este resultado é um indicativo de que a esse nível de significância testado, não foi detectada a variabilidade genética disponível para esses caracteres.

Os coeficientes de variação experimental (CV\%), comumente utilizados para indicar a precisão a qual os experimentos são conduzidos, refletindo assim os cuidados tomados durante a condução e sua avaliação, variaram de 6,7 a $24,5 \%$ para o AP e NEP, respectivamente (Tabela 3 ). Portanto, são valores de magnitude baixa a intermediária segundo a classificação de Gomes (1987), mostrando que houve boa condução experimental. O valor mais alto obtido para o NEP é um indicativo de que este caráter foi mais influenciado pelas variações ambientais. Estes valores sugerem também que o tamanho das amostras (15 panículas) tomadas para a sua mensuração, poderia não ter sido adequado. É aconselhável deste modo, para estudos dessa finalidade, a determinação do tamanho ideal de amostra (número de panícula), o que provavelmente proporcionaria uma redução no $C V$ e possivelmente uma maior precisão nas 
Tabela 3. Resumo das análises de variância dos caracteres avaliados no experimento conduzido com as progênies $R_{3}$ da cultivar IAC 201 no ano agrícola de 1996/97.

\begin{tabular}{|c|c|c|c|c|c|c|}
\hline \multirow[b]{2}{*}{ Caracteres } & \multicolumn{2}{|c|}{ QM } & \multicolumn{2}{|c|}{ GL } & \multirow[b]{2}{*}{ Média } & \multirow[b]{2}{*}{$\begin{array}{l}\text { CV } \\
(\%)\end{array}$} \\
\hline & $\begin{array}{c}\text { Trat. } \\
\text { ajustado }\end{array}$ & $\begin{array}{c}\text { Erro } \\
\text { efetivo }\end{array}$ & $\begin{array}{c}\text { Trat. } \\
\text { ajustado }\end{array}$ & $\begin{array}{c}\text { Erro } \\
\text { efetivo }\end{array}$ & & \\
\hline $\mathrm{AP}(\mathrm{cm})$ & $75,878^{n s}$ & 38,836 & 220 & 18 & 93,0 & 6,7 \\
\hline CIClo (dias) & $41,083^{\mathrm{NS}}$ & 40,810 & 220 & 18 & 74,0 & 8,6 \\
\hline$C P(\mathrm{~cm})$ & $25,323^{\mathrm{NS}}$ & 24,123 & 220 & 18 & 24,0 & 20,4 \\
\hline FER (\%) & $381,901^{\mathrm{NS}}$ & 211,988 & 220 & 18 & 66,2 & 22,0 \\
\hline NEP & $1674,691^{\mathrm{NS}}$ & 1142,808 & 220 & 18 & 137,8 & 24,5 \\
\hline
\end{tabular}

AP: altura de planta;

CICLO: dias para o florescimento;

$C P$ : comprimento de panícula;

FER: fertilidade;

NEP: número de espiguetas por panícula; 
estimativas de parâmetros genéticos. Ainda no tocante a esse comentário, pode-se argumentar que, embora os CVs não tenham sido tão altos, o número de graus de liberdade associado a fonte de variação do erro não foi tão elevado assim, sendo inclusive menor que dos tratamento. Isto se deve ao fato do erro ser estimado a partir das testemunhas, que é uma pressuposição desse delineamento. Uma maneira para aumentar o número de graus de liberdade do erro seria utilizar um maior número de testemunhas (tratamentos comuns) e também, de blocos, proporcionando, consequentemente, um menor valor do quadrado médio para essa fonte de variação.

$\mathrm{Na}$ Tabela 4, está apresentada a análise de variância para a geração $R_{4}$ das progênies da cultivar IAC 201. Além das características avaliadas na geração anterior, foram avaliados também PMG e PROD. Observa-se por esta tabela que houve diferença significativa $(P \leq 0,05)$ somente para FER e PMG, indicando haver pelo menos uma progênie com comportamento diferente das demais para os referidos caracteres. Observa-se também que os CVs para este experimento estiveram dentro dos limites encontrados na literatura (Silva, 1994; Badan, 1999). Verifica-se que os CVs variaram de 8,9 a $57,3 \%$ para o CP e PROD, respectivamente. Embora para os caracteres AP, CICLO e $C P$, esse coeficiente não tenha sido de magnitude elevada, o mesmo não contribuiu para que fossem detectadas diferenças significativas entre as progênies, indicando nesse caso que, se houve variação somaclonal, ela não foi expressiva para os caracteres estudados a este nível de significância. Os maiores valores de CVs apresentados para NEP e PROD deve-se a própria inerência destes caracteres, e em parte, pode-se atribuir a baixa germinação ocorrida em algumas progênies, o que acarretou uma 
Tabela 4. Resumo das análises de variância dos caracteres avaliados no experimento conduzido com as progênies $R_{3}$ da cultivar IAC 201 no ano agrícola de 1997/98.

\begin{tabular}{|c|c|c|c|c|c|c|}
\hline \multirow[b]{2}{*}{ Caracteres } & \multicolumn{2}{|c|}{$Q M$} & \multicolumn{2}{|c|}{$G L$} & \multirow[b]{2}{*}{ Média } & \multirow{2}{*}{$\begin{array}{l}\text { CV } \\
(\%)\end{array}$} \\
\hline & $\begin{array}{c}\text { Trat. } \\
\text { ajustado }\end{array}$ & $\begin{array}{c}\text { Erro } \\
\text { efetivo }\end{array}$ & $\begin{array}{c}\text { Trat. } \\
\text { ajustado }\end{array}$ & $\begin{array}{c}\text { Erro } \\
\text { efetivo }\end{array}$ & & \\
\hline $\mathrm{AP}(\mathrm{cm})$ & $105,333^{\mathrm{NS}}$ & 84,573 & 142 & 18 & 99,3 & 9,3 \\
\hline CICLO (dias) & $84,449^{N S}$ & 79,188 & 142 & 18 & 79,4 & 11,2 \\
\hline$C P(\mathrm{~cm})$ & $5,858^{N S}$ & 4,753 & 142 & 18 & 24,2 & 9,0 \\
\hline FER $(\%)$ & $90,208^{*}$ & 45,548 & 142 & 18 & 72,7 & 9,3 \\
\hline NEP & $3786,574^{\mathrm{NS}}$ & 2896,2040 & 142 & 18 & 175,7 & 30,6 \\
\hline$P M G(g)$ & $48,574^{*}$ & 25,679 & 142 & 18 & 27,5 & 18,4 \\
\hline PROD (g) & $7413,827^{N S}$ & 6615,435 & 142 & 18 & 141,8 & 57,3 \\
\hline \multicolumn{7}{|c|}{ ns: não significativo } \\
\hline \multicolumn{7}{|c|}{ AP: altura de planta; } \\
\hline \multicolumn{7}{|c|}{ CICLO: dias para florescimento; } \\
\hline \multicolumn{7}{|c|}{ CP: comprimento de panícula; } \\
\hline \multicolumn{7}{|c|}{ FER: fertilidade; } \\
\hline \multicolumn{7}{|c|}{ NEP: número de espiguetas por panícula; } \\
\hline PMG: peso & le mil grãos & & & & & \\
\hline PROD: prod & ção de grã & & & & & \\
\hline
\end{tabular}


redução no stand. Em conseqüência disso, a produção média foi baixa, em torno de $2.836 \mathrm{Kg} / \mathrm{ha}$, e, provavelmente, o baixo stand tenha reduzido a competição entre plantas para algumas progênies, fazendo com que as paniculas tivessem tamanhos maiores, e, consequentemente, apresentassem maior número de espiguetas (NEP), embora elas não tenham sido suficientes para influenciar o aumento na produção.

Para o caráter FER, embora tenha sido constatado diferença significativa entre os tratamentos, as progênie que tiveram médias com diferenças significativas foram inferiores ao controle, chegando ficar bem nítido em algumas progênies onde a manifestação fenotípica foi associável à poliploidia. Portanto, na maioria dos casos, a baixa fertilidade pode ser atribuida a ocorrência de progênies provavelmente poliplóides que tiveram baixíssima média de fertilidade. Na literatura, há relatos de que a poliploidia tem afetado acentuadamente a fertilidade dos variantes, devido a irregularidade meióticas (Ogura et al., 1987; Yamagishi et al. 1997).

Com relação ao PMG, que também mostrou diferença significativa para algumas progênies, as médias foram superiores a testemunha e novamente estão associadas à possivel ocorrência de poliploidia. Isto porque a condição poliplóide normalmente ocasiona aumento nos órgãos das plantas. As progênies com médias significativas, referidas como possiveis poliplóide, além da alta esterilidade tiveram aumento no tamanho de grão como pode ser observado através da Figuras 1 , inclusive apresentando arista.

$\mathrm{Na}$ Tabela 5, são apresentados os resultados obtidos no experimento conduzido com as progênies $R_{3}$ da cultivar IAC 165 no ano agrícola de 1996/97. Observa-se, por esta tabela, que apenas o caráter FER apresentou diferença significativa entre as 
progênies. As maiores diferenças em relação à testemunha IAC 165 também ocorreram para as progênies fenotipicamente associáveis à poliploidia.

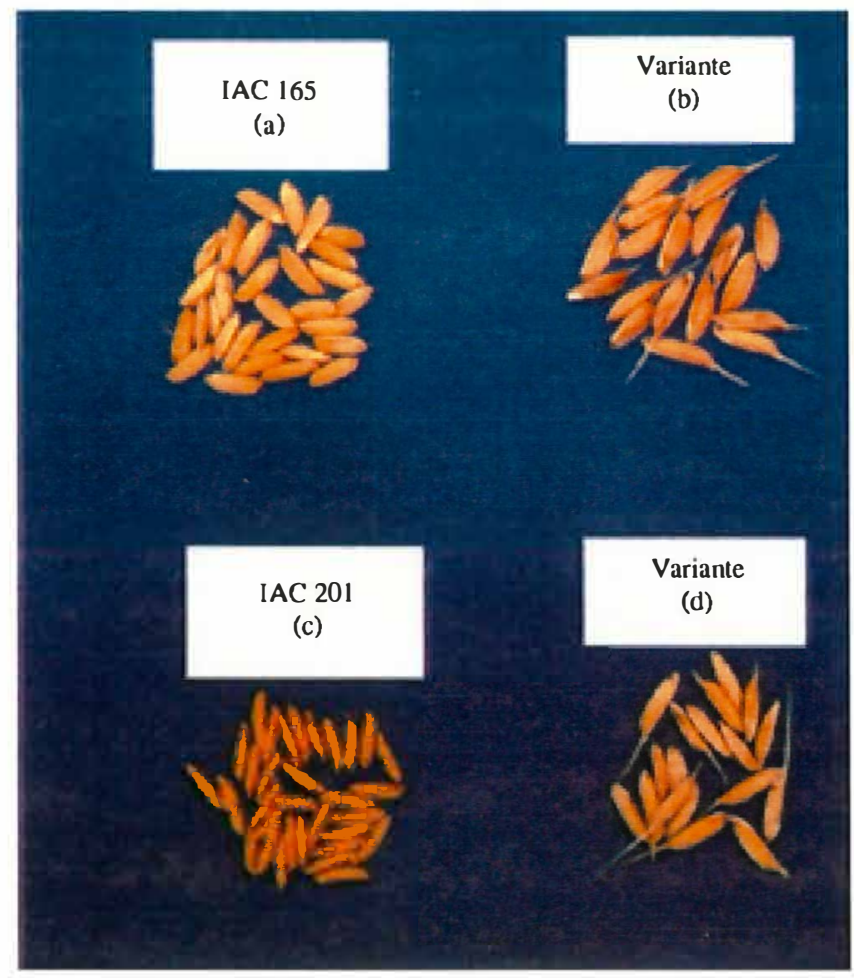

Figura 1. Sementes das cultivares originais IAC 165 (a), IAC 201 (c) e variantes da IAC 165 em (b) e da IAC 201 em (d)

Com relação ao coeficiente de variação (CV), a amplitude de variação foi de $7,0 \%$ para CICLO até $30,5 \%$ para NEP. Nota-se que de uma maneira geral, esses valores são relativamente menores do que os encontrados para as progênies da cultivar IAC 201, indicando que este experimento teve uma melhor precisão. Novamente o NEP foi o caráter que apresentou o maior valor desse coeficiente. Isso deve-se provavelmente à própria inerência do caráter que varia consideravelmente, mesmo quando a amostragem é feita numa mesma planta. 
Tabela 5. Resumo das análises de variância dos caracteres avaliados no experimento conduzido com as progênies $R_{3}$ da cultivar IAC 165 no ano agrícola de 1996/97.

\begin{tabular}{|c|c|c|c|c|c|c|}
\hline \multirow[b]{2}{*}{ Caracteres } & \multicolumn{2}{|c|}{ QM } & \multicolumn{2}{|c|}{ GL } & \multirow[b]{2}{*}{ Média } & \multirow{2}{*}{$\begin{array}{l}C V \\
(\%)\end{array}$} \\
\hline & $\begin{array}{c}\text { Trat. } \\
\text { ajustado }\end{array}$ & $\begin{array}{l}\text { Erro } \\
\text { efetivo }\end{array}$ & $\begin{array}{c}\text { Trat. } \\
\text { ajustado }\end{array}$ & $\begin{array}{l}\text { Erro } \\
\text { efetivo }\end{array}$ & & \\
\hline $\mathrm{AP}(\mathrm{cm})$ & $154,804^{\mathrm{NS}}$ & $\overline{126,033}$ & 711 & 52 & $\overline{112,04}$ & 10,0 \\
\hline CICLO (dias) & $27,928^{\mathrm{NS}}$ & 26,227 & 711 & 52 & 73,36 & 7,0 \\
\hline$C P(\mathrm{~cm})$ & $5,974^{\mathrm{NS}}$ & 5,660 & 711 & 52 & 23,03 & 10,3 \\
\hline FER (\%) & $137,506^{*}$ & 75,094 & 711 & 52 & 81,32 & 10,6 \\
\hline NEP & $1160,635^{\mathrm{NS}}$ & 1159,148 & 711 & 52 & 111,67 & 30,5 \\
\hline
\end{tabular}

ns: não significativo

*: Significativo ao nível de $5 \%$

AP: altura de planta;

CICLO: dias para florescimento;

$C P$ : comprimento de panícula;

FER: fertilidade;

NEP: número de espiguetas por panícula. 
Detectou-se diferenças significativas para FER e PMG no experimento conduzido no ano agricola de 1997/98 (Tabela 6), da mesma maneira como constatado para as progênies da cultivar IAC 201. As progênies que mostraram-se diferentes são fenotipicamente associáveis à poliploidia, sendo que o PMG foi decorrente do aumento do tamanho do grão. Isso é um indicativo de que este fenômeno ocorreu independentemente das cultivares e manifestou-se mais acentuadamente nestes caracteres.

Os CVs variaram de $6,5 \%$ para PMG a $40 \%$ para PROD. Novamente, como ocorreu nas progênies da cultivar IAC 201, o caráter PROD mostrou valores mais elevados, indicando ser ele bastante influenciado pelas condições ambientais, mas também, de se considerar que o tamanho reduzido das parcelas (1 $\mathrm{m}$ linear) tenha contribuído para a umento deste coeficiente. Para PROD, a utilização de parcela de tamanho maior (2 ou $3 \mathrm{~m}$ ) provavelmente proporcionaria menor influencia ambiental, sem aumentar de maneira comprometedora o tamanho da área experimental, uma vez que neste delineamento não se usa repetições para ao tratamentos regulares.

De uma maneira geral, pôde-se constatar que, para as progênies de ambas as cultivares, a variação somaclonal não proporcionou alterações em caracteres que possam ter utilização para melhoria agronômica, uma vez que as fontes de variação, que mostraram-se significativas gerando variantes para FER e PMG, são deletérias, afetando-os negativamente. Portanto, não terá aplicação imediata para o melhoramento do arroz.

No entanto, a não detecção de variantes de interesse pode ser atribuída a própria natureza da variação somaclonal. Ou seja, é um fenômeno que ocorre aleatoriamente, portanto tem maior probabilidade de ocorrência em caracteres qualitativos do 
Tabela 6. Resumo das análises de variância dos caracteres avaliados no experimento conduzido com as progènies $\mathrm{R}_{4}$ da cultivar IAC 165 no ano agrícola de 1997/98.

\begin{tabular}{|c|c|c|c|c|c|c|}
\hline \multirow[b]{2}{*}{ Caracteres } & \multicolumn{2}{|c|}{ QM } & \multicolumn{2}{|c|}{ GL } & \multirow[b]{2}{*}{ Média } & \multirow{2}{*}{$\begin{array}{l}\text { CV } \\
(\%)\end{array}$} \\
\hline & $\begin{array}{c}\text { Trat. } \\
\text { ajustado }\end{array}$ & $\begin{array}{c}\text { Erro } \\
\text { efetivo }\end{array}$ & $\begin{array}{c}\text { Trat. } \\
\text { ajustado }\end{array}$ & $\begin{array}{c}\text { Erro } \\
\text { efetivo }\end{array}$ & & \\
\hline $\mathrm{AP}(\mathrm{cm})$ & $174,922^{\mathrm{NS}}$ & 134,622 & 705 & 52 & $\overline{112,44}$ & 10,3 \\
\hline CICLO (dias) & $42,238^{\mathrm{NS}}$ & 41,806 & 705 & 52 & 77,37 & 8,3 \\
\hline $\mathrm{CP}(\mathrm{cm})$ & $4,955^{\mathrm{NS}}$ & 4,847 & 705 & 52 & 22,03 & 10,0 \\
\hline FER (\%) & $126,368^{*}$ & 67,973 & 705 & 52 & 77,80 & 10,6 \\
\hline NEP & $2311,946^{\mathrm{NS}}$ & 2122,528 & 705 & 52 & 135,93 & 33,9 \\
\hline PMG (g) & $9,222^{*}$ & 4,737 & 705 & 52 & 33,60 & 6,5 \\
\hline PROD (g) & $5718,933^{\mathrm{NS}}$ & 5202,757 & 705 & 52 & 180,23 & 40,0 \\
\hline
\end{tabular}

ns: não significativo

*: Significativo ao nível de $5 \%$

AP: altura de planta;

CICLO: dias para florescimento;

CP: comprimento de panícula;

FER: fertilidade;

NEP: número de espiguetas por panícula;

PMG: peso de mil grãos;

PROD: produção de grãos. 
que em quantitativos. Deve-se considerar ainda que o número de plantas regeneradas que originaram as progênies pode não ter sido suficiente para proporcionar o surgimento de variantes para os caracteres de interesse agronômico, tais como redução de ciclo e altura de planta, uma vez que eles são governados por um elevado número de genes.

Observa-se também que houve diferença para as progênies das duas cultivares em ambos os anos de avaliação para - caráter FER, com exceção apenas para o ano agrícola de 1996/97 para as progênies da cultivar IAC 201. No entanto, podese inferir que, para esse ano, o CV apresentou magnitude relativamente alta em relação aos demais, o que pode ter dificultado a detecção de diferença significativa para o referido caráter.

Uma outra consideração que deve ser feita é de que o delineamento experimental utilizado pode não ter proporcionado sensibilidade suficiente para identificar alterações nos caracteres de efeito menos pronunciados (quantitativos), uma vez que, em uma das progênies da cultivar IAC 165, foi observado um adensamento de panicula decorrente do encurtamento dos ramos secundários que manifestou-se tanto em $R_{3}$ com em $R_{4}$ (Figura 2 ), bem como algumas progênies selecionadas visualmente na geração $R_{3}$ não mostraram diferença significativa na geração $R_{4}$. Talvez com a utilização de parcelas maiores ou maior número de testemunhas pudesse detectar diferenças significativas entre tais tratamentos, mesmo utilizando este delineamento. 


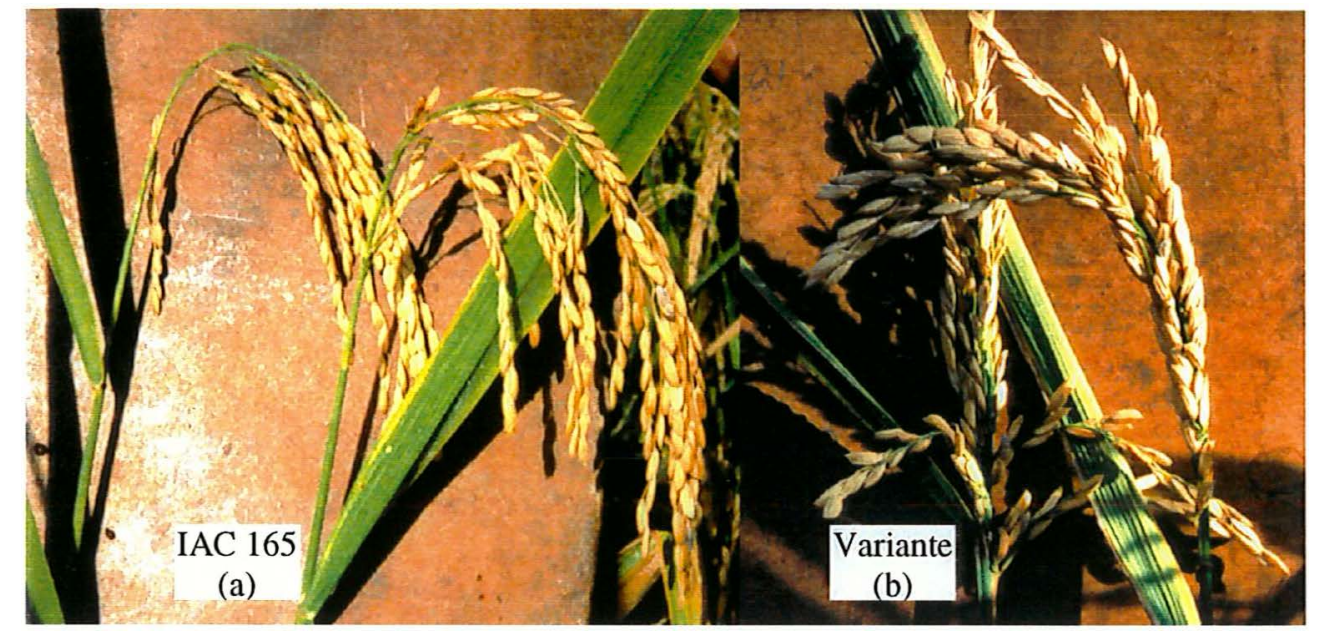

Figura 2. Panículas da cultivar original IAC 165 (a) e panícula adensada de progênie variante em (b). 


\subsection{Estimativas dos parâmetros genéticos}

Nas Tabelas 7, 8, 10 e 11, são apresentados os valores estimados dos parâmetros genéticos, variância genética $\left(\sigma_{g}^{2}\right)$, coeficiente de variação genética $(C V g)$, índice b $(b)$ e herdabilidade no sentido amplo $\left(h^{2}\right)$.

Com relação a $\sigma_{g}^{2}$, é importante enfatizar que a sua comparação quando envolve diferentes caracteres é sempre dificultada, pois ela é influenciada pela magnitude dos dados. Assim, deve-se utilizar outros parâmetros que podem ser diretamente comparáveis. Um deles é o coeficiente de variação genética $(\mathrm{CVg})$ que estima os desvios genéticos em relação a média do caráter (Vencovsky, 1987). Em relação aos experimentos conduzidos com as progênies da cultivar IAC 201, observa-se na Tabela 7, que o caráter FER apresentou 0 maior $C V g$ e 0 menor valor foi obtido para CICLO, evidenciando que, proporcionalmente a média, houve maior variabilidade para o FER. Na Tabela 8 referente a geração $R_{4}$, pode ser observado que o maior $\mathrm{CVg}$ também ocorreu para PROD e novamente o menor para CICLO. Esses menores valores estimados para $\mathrm{CVg}$ encontrados para FER nesse experimento, pode ser atribuido ao fato do caráter ter sido mais influenciado negativamente pelas manifestações fenotípicas das progênies por serem possíveis poliplóides que tiveram alto grau de esterilidade, não sendo por isso selecionados.

Quando se compara os valores de CVg para os caracteres em comum, percebe-se que houve uma certa tendência de manutenção da variabilidade genética. Observando a Tabela 9 , nota-se que para os caracteres CICLO e NEP houve um aumento dessa variabilidade, indicando a princípio, nesse caso, que a 
Tabela 7. Estimativas dos parâmetros genéticos: variância genética $\left(\sigma_{\mathrm{g}}^{2}\right)$, coeficiente de variação genético $(C V g)$, indice $b(b)$ e herdabilidade $\left(h^{2}\right)$, para os caracteres avaliados no experimento conduzido com as progênies $R_{3}$ da cultivar IAC 201 no ano agrícola de 1996/97.

\begin{tabular}{lcccc}
\hline & \multicolumn{4}{c}{ PARÂMETROS GENÉTICOS } \\
\cline { 2 - 5 } Caracteres & $\sigma_{\mathrm{g}}^{2}$ & $\mathrm{CV}$ & $\mathrm{b}$ & $\mathrm{h}^{2}$ \\
\hline $\mathrm{AP}(\mathrm{cm})$ & 37,042 & 6,5 & 0,97 & 48,82 \\
CICLO (dias) & 0,273 & 0,7 & 0,08 & 0,66 \\
CP (cm) & 1,201 & 4,6 & 0,22 & 4,74 \\
FER (\%) & 169,913 & 19,7 & 0,89 & 44,50 \\
NEP & 531,883 & 16,7 & 0,68 & 31,76 \\
\hline
\end{tabular}

AP: altura de planta;

CICLO: dias para florescimento;

CP: comprimento de panícula;

FER: fertilidade;

NEP: número de espiguetas por panícula 
Tabela 8. Estimativas dos parâmetros genéticos: variância genética $\left(\sigma_{g}^{2}\right)$, coeficiente de variação genético $(C \vee g)$, indice b (b) e herdabilidade $\left(h^{2}\right)$, para os caracteres avaliados no experimento conduzido com as $R_{3}$ progênies da cultivar IAC 201 no ano agrícola de 1997/98.

\begin{tabular}{lcccc}
\hline & \multicolumn{4}{c}{ PARÂMETROS GENÉTICOS } \\
\cline { 2 - 5 } Caracteres & $\sigma_{\mathrm{g}}^{2}$ & $\mathrm{CV} g$ & $\mathrm{~b}$ & $\mathrm{~h}^{2}$ \\
\hline AP $(\mathrm{cm})$ & 20,760 & 4,6 & 0,49 & 19,70 \\
CICLO (dias) & 5,262 & 2,9 & 0,26 & 6,23 \\
CP $(\mathrm{cm})$ & 1,106 & 4,3 & 0,48 & 18,90 \\
FER (\%) & 44,661 & 9,2 & 0,99 & 49,50 \\
NEP & 890,334 & 17,0 & 0,55 & 23,51 \\
PMG (g) & 22,895 & 17,4 & 0,94 & 47,13 \\
PROD (g) & 798,391 & 19,9 & 0,35 & 10,77 \\
\hline
\end{tabular}

AP: altura de planta;

CICLO: dias para florescimento;

CP: comprimento de panícula;

FER: fertilidade;

NEP: número de espiguetas por panícula;

PMG: peso de mil grãos;

PROD: produção de grãos. 
Tabela 9. Valores de coeficiente de variação genético ( $\mathrm{CVg}$ ) estimados nos anos agrícolas de 1996/97 e 1997/98 e valor da alteração da variabilidade entre os dois anos para as progênies do cultivar IAC 201.

\begin{tabular}{lccc}
\hline \multirow{2}{*}{ Caracteres } & \multicolumn{2}{c}{ CVg } & $\begin{array}{c}\text { Alteração na } \\
\text { variabilidade }\end{array}$ \\
\cline { 2 - 3 } & $1996 / 97$ & $1997 / 98$ & $-1,9$ \\
\hline AP (cm) & 6,5 & 4,6 & $+2,2$ \\
CICLO (dias) & 0,7 & 2,9 & $-0,3$ \\
CP (cm) & 4,6 & 4,3 & $-10,5$ \\
FER (\%) & 19,7 & 9,2 & $+0,3$ \\
NEP & 16,7 & 17,0 & \\
\hline
\end{tabular}

AP: altura de planta;

CICLO: dias para florescimento;

$C P$ : comprimento de panícula;

FER: fertilidade;

NEP: número de espiguetas por panícula. 
variação somaclonal propiciou incremento na variabilidade desses caracteres. No entanto, esses resultados devem ser visto com ressalvas, haja visto que devido o CVe ser uma medida relativa, ela pode ser influenciada pela média do caráter e, também pela magnitude do quadrado médio do erro e, não necessariamente, pela redução propriamente dita da $\sigma_{g}^{2}$. Além disso, como as progênies são as mesmas nos dois anos, deve-se também atribuir essa diferença aos fenômenos ambientais ocorrido de um ano para o outro.

Observando novamente a Tabela 9, constata-se que o caráter $\mathrm{FER}$ foi o que apresentou a menor redução no $\mathrm{CVg}$, porém, ressalta-se que tal fenômeno deva ser atribuido aos fenômenos ambientais decorrentes de um ano para outro.

Mesmo sendo um parâmetro bastante informativo da variação genética de um dado caráter, o CVg isoladamente nem sempre reflete a maior ou menor possibilidade de sucesso para a seleção. Um outro parâmetro bastante interessante é a relação entre o CVg e o CVe, denominado de índice b (Vencovsky, 1987). Esse coeficiente estima a proporção de variância genética sobre a ambiental e quando for maior que a unidade indica situação favorável para seleção, podendo até certo ponto substituir a estimativa de $\mathrm{h}^{2}$.

Neste experimento, constatou-se que o b foi menor que a unidade para todos os caracteres nos dois anos agrícolas, embora para AP em 1996/97 ele tenha se mostrado muito próximo de um. Esses resultados apontam para uma baixa disponibilidade de variabilidade genética como já havia sido mencionado anteriormente. Verifica-se que, de uma maneira geral, os caracteres que mais se aproximaram da unidade foram AP em 1996/97, FER e PMG nos dois anos agricolas. Observa-se também 
que estes caracteres foram os únicos que mostraram diferenças significativas entre as progênies, indicando que a seleção pode ser efetiva se aplicada a eles. No entanto, como já mencionado para FER no experimento conduzido no ano agricola de 1996/97, as progênies que mostraram diferenças para PMG são os mesmos prováveis poliplóides.

O coeficiente de $\mathrm{h}^{2}$ é uma estimativa importante utilizada pelo melhorista, pois ele estima a proporção da variação fenotipica que é utilizada na seleção (Falconer, 1987). Através das Tabelas 7 e 8, verifica-se que, para as progênies da cultivar IAC 201, esse coeficiente esteve abaixo de $50 \%$, chegando inclusive assumir o valor de 0,66\% para o CICLO no ano 1996/97. As baixas herdabilidades no sentido amplo encontradas, limitam sensivelmente o sucesso com a seleção. Porém, segundo Falconer (1987), este parâmetro genético é dependente das condições ambientais, da variabilidade genética presente nas amostras e do método utilizado para sua obtenção. Como os CVs obtidos foram de uma maneira geral baixos, deve-se atribuir aos valores de $\mathrm{h}^{2}$ à baixa variabilidade genética disponivel. De um modo geral, os resultados indicam que a passagem desta cultivar pelo cultivo in vitro não contribuiu para a geração de variabilidade aproveitável em programas de melhoramento, como ficou comprovado através das estimativas dos parâmetros genéticos.

Nas Tabelas 10 e 11, são expostos os resultados dos parâmetros genéticos $\sigma_{g}^{2}, \quad C V g$, coeficiente $b$ e $h^{2}$ para os experimentos conduzidos com as progênies da cultivar IAC 165 no anos agricolas de 1996/97 e 1997/98. Percebe-se, pela Tabela 10, que o maior valor de CVg estimado foi para o caráter FER $(9,7 \%)$ e o menor para NEP $(1,1 \%)$. Na Tabela 11 , o maior CVg estimado foi para o caráter PROD e o menor para CICLO. Quando se compara 
Tabela 10. Estimativas dos parâmetros genéticos: variância genética $\left(\sigma_{\mathrm{g}}^{2}\right)$, coeficiente de variação genético $(\mathrm{CVg})$, indice b (b) e herdabilidade $\left(\mathrm{h}^{2}\right)$, para os caracteres avaliados no experimento conduzido com as progênies $R_{3}$ da cultivar IAC 165 no ano agrícola de $1996 / 97$.

\begin{tabular}{lcccc}
\hline \multirow{2}{*}{ Caracteres } & \multicolumn{4}{c}{ PARÂMETROS GENÉTICOS } \\
\cline { 2 - 5 } & $\sigma_{g}^{2}$ & $\mathrm{CVg}$ & $\mathrm{b}$ & $\mathrm{h}^{2}$ \\
\hline AP (cm) & 28,771 & 4,8 & 0,48 & 18,58 \\
CICLO (dias) & 1,701 & 1,8 & 0,25 & 6,00 \\
CP (cm) & 0,134 & 1,6 & 0,15 & 2,24 \\
FER (\%) & 62,412 & 9,7 & 0,91 & 45,38 \\
NEP & 1,486 & 1,1 & 0,03 & 0,13 \\
\hline
\end{tabular}

AP: altura de planta;

CICLO: dias para florescimento;

CP: comprimento de panícula;

FER: fertilidade;

NEP: número de espiguetas por panícula;

PMG: peso de mil grãos e PROD: produção de grãos. 
Tabela 11. Estimativas dos parâmetros genéticos: variância genética $\left(\sigma_{g}^{2}\right)$, coeficiente de variação genético $(C \vee g)$, indice $b(b)$ e herdabilidade $\left(h^{2}\right)$, para os caracteres avaliados no experimento conduzido com as progenies $R_{4}$ da cultivar IAC 165 no ano agrícola de $1997 / 98$.

\begin{tabular}{lcccc}
\hline & \multicolumn{4}{c}{ PARÂMETROS GENÉTICOS } \\
Caracteres & $\sigma_{\mathrm{g}}^{2}$ & $\mathrm{CVg}$ & $\mathrm{b}$ & $\mathrm{h}^{2}$ \\
\cline { 2 - 5 } AP (cm) & 40,300 & 5,6 & 0,54 & 23,04 \\
CICLO (dias) & 0,432 & 0,8 & 0,10 & 1,02 \\
CP (cm) & 0,108 & 1,5 & 0,15 & 2,18 \\
FER (\%) & 58,395 & 9,8 & 0,92 & 46,21 \\
NEP & 189,418 & 10,1 & 0,30 & 8,20 \\
PMG (g) & 4,485 & 6,3 & 0,97 & 48,63 \\
PROD (g) & 516,176 & 12,6 & 0,31 & 9,00 \\
\hline
\end{tabular}

AP: altura de planta;

CICLO: dias para florescimento;

CP: comprimento de panícula;

FER: fertilidade;

NEP: número de espiguetas por panícula;

PMG: peso de mil grãos;

PROD: produção de grãos. 
os dois cultivares nos dois anos agricolas, observa-se que há uma tendência de haver uma menor variabilidade genética para PROD e uma menor para o ciclo.

Observando a Tabela 12, constatou-se que houve um aumento na variabilidade genética para os caracteres AP, FER e NEP e uma redução para CICLO e CP. No entanto, os comentários feitos para as progênies da cultivar 201, são válidos também para as progênies da IAC 165, ou seja, essas alterações observadas se devem aos caracteres avaliados no experimento conduzido com as progênies da cultivar IAC 201 no ano agrícola de 1997/98, principalmente aos efeitos do ambiente e de um ano para outro.

$O$ indice $b$ foi, para todas as característica nos dois anos agricola, inferior a unidade e novamente os que apresentaram maior valor foram os que mostraram diferenças significativas. Consequentemente, as $\mathrm{h}^{2}$ foram também baixas indicando que 0 sucesso com a seleção é mais limitado. No entanto, para aqueles caracteres que tiveram estimativas de $h^{2}$ maiores, é possivel obter maior sucesso com a seleção num menor espaço de tempo.

Através dos parâmetros genéticos apresentados, nota-se que houve uma baixa disponibilidade de variabilidade genética confirmando os resultados obtidos nas análises de variância. Deve-se atribuir este resultados à inerência dos caracteres quantitativos que ocorrem com menor freqüência em decorrência da variação somaclonal. 
Tabela 12. Valores de coeficiente de variação genético $(\mathrm{CVg})$ estimados nos anos agricolas de 1996/97 e 1997/98 e valor da alteração da variabilidade entre os dois anos para as progênies do cultivar IAC 165.

\begin{tabular}{lccc}
\hline \multicolumn{1}{c}{ Caracteres } & \multicolumn{2}{c}{ CVg } & $\begin{array}{c}\text { Alteração na } \\
\text { variabilidade }\end{array}$ \\
\cline { 2 - 3 } & $1996 / 97$ & $1997 / 98$ & $+0,8$ \\
AP $(\mathrm{cm})$ & 4,8 & 5,6 & $-1,0$ \\
CICLO (dias) & 1,8 & 0,8 & $-0,1$ \\
CP $(\mathrm{cm})$ & 1,6 & 1,5 & $+0,1$ \\
FER $(\%)$ & 9,7 & 9,8 & $+9,0$ \\
NEP & 1,1 & 10,0 & \\
\hline
\end{tabular}

AP: altura de planta;

CICLO: dias para florescimento;

$C P$ : comprimento de panícula;

FER: fertilidade;

NEP: número de espiguetas por panícula; 


\subsection{Agrupamento de médias de SCOTT-KNOTT}

Foram agrupadas apenas as médias dos caracteres que mostraram diferenças significativas pelas análises de variância. Observa-se pela Tabela 13 que as progênies de ambas cultivares que mostraram-se diferentes tiveram uma alta redução na fertilidade em relação às testemunhas.

Para as progênies da IAC 165 no ano agrícola de $1996 / 97$, as médias foram classificadas em dois grupos diferentes da testemunha $A$ e B. As diferenças em torno da testemunha variaram negativamente de 47,33 a $73,77 \%$. Para as progênies da cultivar IAC 201 no ano agrícola de 1997/98, quatro distinguiram-se negativamente, sendo elas classificadas em grupos distintos ( $\mathrm{A}$ e B), as suas diferenças em relação a testemunha variaram de 41,69 a $64,71 \%$. As progênies da IAC 165 que mostraram-se significativamente diferentes da testemunha no ano agrícola de 1997/98, foram as mesmas do ano anterior. Houve apenas alteração na ordem de agrupamento das progênies, e as diferenças variaram de 45,66 a $80,31 \%$.

$\mathrm{Na}$ Tabela 14, são apresentadas as progênies de ambas as cultivares que mostraram diferença significativa para PMG em relação as testemunhas (IAC 201 e IAC 165). Para as progênies da IAC 201, dois grupos foram constatados diferindo com valores superiores da testemunha, e sua amplitude de variação foi de 9,93 a 22\%. Para as progênies da IAC 165, as de comportamento diferentes também foram classificadas em dois grupos distintos ao da testemunha, e variaram de 10,72 a 20,32 g a mais. Todas essas progênies, que apresentaram diferenças significativas em relação as testemunhas para os dois caracteres 
(FER e PMG), apresentaram fenotipicamente a aparência de plantas poliplóides.

Tabela 13. Relação das progênies das cultivares IAC 165 e IAC 201 que diferiram estatisticamente das originais para o caráter FER com suas respectivas médias agrupadas pela metodologia de SCOTT-KNOTT e sua diferença em relação às testemunhas nos anos agrícolas de 1996/97 e 1997/98.

\begin{tabular}{|c|c|c|c|c|c|c|c|c|c|c|c|}
\hline \multicolumn{12}{|c|}{ FERTILIDADE (FER) } \\
\hline \multicolumn{4}{|c|}{$1996 / 97$} & \multicolumn{8}{|c|}{$1997 / 98$} \\
\hline \multicolumn{4}{|c|}{ Progênies da IAC 165} & \multicolumn{4}{|c|}{ Progênies da IAC 201} & \multicolumn{4}{|c|}{ Progênies da IAC 165} \\
\hline $\begin{array}{c}\mathrm{N}^{0} \\
\text { progênies }\end{array}$ & $\begin{array}{c}\text { Modias } \\
(\%)\end{array}$ & Grupos & $\begin{array}{l}\text { Diforença } \\
\text { (\%) }\end{array}$ & $\begin{array}{c}\mathrm{N}^{Q} \\
\text { progênies }\end{array}$ & $\begin{array}{c}\text { Modias } \\
(\%)\end{array}$ & Grupos & $\begin{array}{l}\text { Diferença } \\
(\%)\end{array}$ & $\begin{array}{c}\mathrm{N}^{Q} \\
\text { progênies }\end{array}$ & $\begin{array}{c}\text { Médias } \\
(\%)\end{array}$ & Grupos & $\begin{array}{c}\text { Diferença } \\
(\%)\end{array}$ \\
\hline 23 & 17,46 & $A$ & $-59,96$ & 10 & 30,44 & $A$ & $-55,68$ & 23 & 33,94 & B & $-51,62$ \\
\hline 25 & 13,61 & $A$ & $-63,81$ & 16 & 21,41 & $A$ & $-64,71$ & 25 & 39,90 & $B$ & $-45,66$ \\
\hline 26 & 16,07 & $A$ & $-61,35$ & 17 & 44,43 & B & $-41,69$ & 26 & 21,59 & A & $-63,97$ \\
\hline 27 & 30,09 & B & $-47,33$ & 19 & 35,98 & B & $-50,14$ & 27 & 20,21 & A & $-65,35$ \\
\hline 38 & 31,10 & B & $-46,32$ & IAC 201 & 86,12 & C & & 38 & 5,25 & $A$ & $-80,31$ \\
\hline 39 & 26,02 & $A$ & $-51,40$ & & & & & 39 & 20,13 & A & $-65,43$ \\
\hline 40 & 7,29 & $A$ & $-70,12$ & & & & & - & - & - & - \\
\hline 44 & 22,49 & $A$ & $-54,93$ & & & & & 44 & 27,08 & $A$ & $-58,48$ \\
\hline 45 & 24,27 & $A$ & $-53,15$ & & & & & 45 & 35,66 & $\mathrm{~B}$ & $-49,90$ \\
\hline 46 & 13,40 & $A$ & $-64,02$ & & & & & 46 & 27,60 & A & $-57,96$ \\
\hline 47 & 22,59 & $A$ & $-54,83$ & & & & & 47 & 24,85 & $A$ & $-60,71$ \\
\hline 49 & 4,27 & $A$ & $-73,15$ & & & & & 49 & 9,22 & $A$ & $-76,34$ \\
\hline 50 & 20,35 & $A$ & $-57,07$ & & & & & 50 & 32,15 & $B$ & $-53,41$ \\
\hline 57 & 3,65 & A & $-73,77$ & & & & & - & $=$ & - & - \\
\hline 58 & 10,57 & $A$ & $-66,85$ & & & & & 58 & 20,20 & $A$ & $-65,36$ \\
\hline IAC 165 & 77,42 & $C$ & & & & & & IAC 165 & 85,56 & $C$ & \\
\hline
\end{tabular}

* Grupos com letras distintas diferem entre si ao nível $5 \%$ de probabilidade pelo teste de $\chi^{2}$. 
Tabela 14. Relação das progênies das cultivaras IAC 165 e IAC 201 que diferiram estatisticamente das originais para o caráter PMG com suas respectivas médias agrupadas pela metodologia de SCOTT-KNOTT e sua diferença em relação às testemunhas.

\begin{tabular}{|c|c|c|c|c|c|c|c|}
\hline \multicolumn{8}{|c|}{ PESO DE MIL GRÃOS (PMG) } \\
\hline \multicolumn{8}{|c|}{$1997 / 98$} \\
\hline \multicolumn{4}{|c|}{ Progênies da IAC 201} & \multicolumn{4}{|c|}{ Progênies da IAC 165} \\
\hline $\begin{array}{c}\mathrm{N}^{0} \\
\text { progênies }\end{array}$ & $\begin{array}{l}\text { Médias } \\
(\mathrm{g})\end{array}$ & $\underset{\star}{\text { Grupos }}$ & $\begin{array}{l}\text { Diferença } \\
\text { (g) }\end{array}$ & $\begin{array}{c}\mathrm{N}^{\mathbf{0}} \\
\text { progênies }\end{array}$ & $\begin{array}{l}\text { Médias } \\
\text { (g) }\end{array}$ & $\begin{array}{l}\text { Diferença } \\
\text { (g) }\end{array}$ & $\underset{\star}{\text { Grupos }}$ \\
\hline 10 & 35.40 & $B$ & +10.15 & 23 & 43.92 & +10.72 & $B$ \\
\hline 16 & 37.64 & B & +12.39 & 25 & 51.52 & +18.32 & C \\
\hline 17 & 35.18 & B & +9.93 & 26 & 48.72 & +15.52 & C \\
\hline 19 & 47.64 & C & +22.39 & 27 & 50.49 & +17.29 & C \\
\hline \multirow[t]{10}{*}{ IAC 201} & 25.25 & $A$ & & 38 & 44.72 & +11.52 & $B$ \\
\hline & & & & 39 & 45.72 & +12.52 & C \\
\hline & & & & 44 & 45.82 & +12.52 & C \\
\hline & & & & 45 & 46.72 & +13.52 & C \\
\hline & & & & 46 & 48.15 & +14.95 & C \\
\hline & & & & 47 & 53.52 & +20.32 & C \\
\hline & & & & 49 & 53.92 & +20.72 & C \\
\hline & & & & 50 & 54.48 & +21.28 & C \\
\hline & & & & 58 & 54.92 & +21.72 & C \\
\hline & & & & IAC 165 & 33.20 & & A \\
\hline
\end{tabular}

* Grupos com letras distintas diferem entre si ao nível $5 \%$ de probabilidade pelo teste de $\chi^{2}$ 


\subsection{Consideraçōes gerais}

Para fins de melhoramento, as caracteristicas de maior relevância avaliadas no presente trabalho e que se esperava obter variantes para as duas cultivares são redução no ciclo e na altura de planta. Pois para ambas as cultivares, a redução no ciclo proporcionaria maior rapidez para retirada da cultura do campo, proporcionando redução nos riscos de perda por adversidades climáticas, além de propiciar a rotação de cultura, aumentando assim a produtividade da área. A redução no porte da planta, além de reduzir os riscos de perdas decorrentes do acamamento, proporcionaria redução no espaçamento de cultivo, aumentando deste modo o número de plantas por área. Outra vantagem, é que cultivares com essas caracteristicas podem ser plantadas em solos de altas fertilidade ou se fazer adubações pesadas sem que elas acamem. Para as progênies da cultivar IAC 165, também seria interessante a obtenção de somaclones com classe de grão longofino, uma vez que esta é uma característica desejável para a referida cultivar.

Características de grande importância como resistência ou tolerância à brusone, que é a principal doença da cultura do arroz, não foi avaliadas, uma vez que as condições e o local em que foram conduzidos os experimentos não tem proporcionado o aparecimento de patógenos.

Quanto as demais características avaliadas, elas só teriam importância caso fossem obtidos genótipos mais precoces ou de porte baixo. Neste contexto, fica evidente que a variação somaclonal deve ser vista com ressalvas principalmente quando se objetiva melhoria de caracteres quantitativos em cultivares que já apresentem boa adaptabilidade. 
Um outro aspecto que deve-se considerar é que, a partir de escutelo de sementes germinadas, foi possivel regenerar plantas de ambas as cultivares num período de tempo relativamente curto (em torno de 60 dias), uma vez que o objetivo não era obter somaclones. No entanto, a literatura aponta a maior duração do tempo de cultivo in vitro como um fator que aumenta a frequência de variação somaclonal (Peschke, et al. 1992; Fluminhan \& Kameya, 1996). Portanto, pode ser que este periodo não tenha sido suficiente para que houvesse maior frequência de alterações genéticas nas plantas regeneradas.

Deve ainda salientar que o número de plantas que apresentaram características de poliplóides pode ser considerado alto, 4 para IAC 201 e 13 para a IAC 165 num total de 20 e 38 plantas regeneradas, respectivamente, evidenciando que os eventos que proporcionaram tais alterações são relativamente frequêntes.

Quanto ao delineamento experimental, muito embora nesta pesquisa não tenha comprometido os objetivos do experimento, em pesquisas desta natureza deve-se tomar precauções no sentido de se obter maior sensibilidade das análises estatísticas. Para esta finalidade, o emprego de um maior número do blocos e de testemunhas tornaria mais eficiente a seleção dos melhores genótipos. Ao se elaborar projetos objetivando variantes de interesse agronômico, deve-se também optar pelo uso de uma seleção visual antes de delinear os experimentos com o propósito de reduzir o número de progênies. Por este procedimento, as progênies supostamente poliplóides observadas no presente trabalho seriam eliminadas, não entrando nos experimentos de gerações posteriores. 


\section{Conclusões}

a) Através da análise de variância detectou-se diferenças significativas para os caracteres fertilidade e peso $100 \mathrm{mil}$ grãos nas as progênies de ambas as cultivares;

b) Somente as progênies com manifestação fenotípica de poliplóides de ambas as cultivares, mostraram diferenças significativas, sugerindo que a frequência de alterações cromossômicas foi alta;

c) Os resultados das análises estatísticas permitem inferir que para estudos dessa natureza, utilizando-se esse delineamento, deve-se dar preferência ao uso de parcelas de tamanho maior;

d) Os parâmetros genéticos analizados mostram baixa variabilidade genética disponivel nos caracteres estudados, inferindo-se assim, que a regeneração de plantas a partir de protoplastos de calos primários do escutelo destas duas cultivares, num período de cultivo in vitro de aproximadamente 60 , dias não gerou variabilidade esperada. 


\section{REFERÊNCIAS BIBLIOGRÁFICAS}

ADKINS, S. W.; SHIRAISHI, T.; MACCOMB, J. A; RATANOPOL, S.; KUPKANCHANAKUL, T.; ARMSTRONG, L. J.; SCHULTZ, A. L. Somaclonal variation in rice - submergence tolerance and other agronomic characters. Physiologia Plantarum, v.80, p.647-654, 1990.

ADKINS, S.W.; KUNANUVATCHAIDACH, R.; GODWIN, I.D. Somaclonal variation in rice-drought tolerance and other agronomic characters. Australian Journal of Botany, v.43, n.2, p.201-209, 1995.

ADKINS, S.W.; SHIRAISHI, T.; McCOMB, J.A. Somaclonal variation for submergence tolerance in rice. Proceeding of the 1987. International Deepwater rice Workshop, Proceedings $337-341,1987$.

ANUÁRIO ESTATÍSTICO DA AGRICULTURA BRASILEIRA-1998, p.134-144, 1996.

ANGLADETTE, A. El arroz. Barcelona: Blume, 1963. 867p. 
ANDO, A.; TULMANN NETO, A.; MENTEN, J.O.M. Sodium azide mutagenicity in rice seeds. In: Proc. 2nd. Japan-Brazil Symp.Sci. \& Technol., São Paulo, p.192-199, 1980.

ARAÚJO, L.G.; PRABHU, A.S.; FREIRE, A.B. Variação somaclonal na cultivar de arroz IAC-47 para resistencia parcial à brusone. Fitopatologia Brasileira, v.22, n.2, p.125-130, 1997.

ARMSTRONG, K.C.; NAKAMURA, C.; KELLER, W.A. Karyotype instability in tissue regenerants of Triticale ( $x$ Triticosecale Wittmack) cv. 'Welsh' from 6-month-old callus cultures. Zeitschrift für Pflanzenzüchtung, v. 91, n.3, p.233-245, 1983.

AZZINI, L.E.; BASTO, C.B.;VILLELA, O.V.; GALLO, P.B.; SOAVE, J.; CASTRO, L.H.S.M.; TISSELLI FILHO, O. Melhoramento do arroz: I. Comportamento de cultivares e linhagens de arroz irrigado no Estado de São Paulo em 1990/91 e 1991/92. Bragantia, v.54, n.2, p.287-96, 1995.

BADAN, A.C.C. Estimativas de parâmetros genéticos e fenotípicos em duas populações de arroz de sequeiro e implicações para o melhoramento. Piracicaba, 1999. 51p. Dissertação (Mestrado) - Escola Superior de Agricultura "Luiz de Queiroz", Universidade de São Paulo.

BARBOSA, M.H.P. Capacidade combinatória e comparação entre critérios de seleção de clones de batata (Solanum tuberosum L.). Lavras, 1996, 141p. Tese (Doutorado) - Universidade Federal de Lavras. 
BAYLISS, M.W. Chromosomal variation in plant tissues in culture. International Review of Cytology v.11A,p. 113-144, 1980. supplement.

BEARZOTI, E. Comparação entre métodos estatísticos na avaliação de clones de batata em um programa de melhoramento. Lavras, 1994. 128p. Dissertação (Mestrado) Escola Superior de Agricultura de Lavras.

BENZION, G.; PHILLIPS, R,L.; RINES, H.W. Case histories of genetic variability in vitro: oats and maize. In: VASIL, I.K. (Ed.) Cell culture and somatic cell genetics of plants. New York: Academic Press, 1986.cap. 22, p.435-448.

BERTIN, P.; BOUHARMONT, J.; KINET, J.M. Somaclonal variation and improvement in chilling tolerance in rice: changes in chilling-induced electrolyte leakage. Plant Breeding, v.115, n. 4 , p.268-272, 1996.

BERTIN, P.;BUSOGORO, J.P.;TILQUIN, J.P.; KINET, J.M.; BOUHARMONT, J. Field evaluation and selection of rice somaclonal variants at different altitudes. Plant Breeding, v. 115, n. 3 p. $183-189,1996$

BRASIL. Ministério da Agricultura. Regras para análise de sementes. Brasilia: Departamento Nacional de Produção Vegetal, 1992. 365p.

BREARS, T.; CURTIS, C.J.; LONSDALE, D.M. A specific rearrangement of mitochondrial DNA induced by tissue culture. Theoretical and Applied Genetics, v.77, p.620-624, 1989. 
BREIMAN, A.; SHIMRON-ABARBANELL, D. Comprehensive molecular characterization of tissue-culture-derived Hordeum marinum plants. Theoretical and Applied Genetics, v.83, p.71-80, 1991.

BRETTEL, R.I.S.; DENNIS, E.S. Reactivation of a silent AC following tissue culture is associated with heritable alterations in its methylation pattern. Molecular General Genetics, v.229, n.3, p.365-372, 1991.

BROWN, P.T.H. DNA methylation in plants and its role in tissue culture. Genome, v.3 1, n.2, p.717-729, 1989.

BROWN, P.T.H.; GÕBEL, E.; LÕRZ, H. RFLP analysis of Zea mays callus cultures and their regenerated plants. Theoretical and Applied Genetics, v.81, n.2, p.227-232. 1991.

COORDENADORIA DE ASSISTÉNCIA TÉCNICA INTEGRAL. Arroz: recomendações técnicas para o Estado de São Paulo. Campinas: Comissão Técnica de Arroz da Secretaria de Agricultura e Abastecimento, 1996. 70p.

CARMONA, P.S. Melhoramento do arroz irrigado na região sul do Brasil. Lavoura Arrozeira, v.42, n.387, p.14-16, 1989.

CASCUDO, L.C. História da alimentação no Brasil. Belo Horizonte: Itatiaia; São Paulo: EDUSP, 1983.

CHOMET, P.S.; WESSLER, S.; DELLAPORTA, L.S. Inactivation of the maize transposable element activator $(A C)$ is associated with DNA modification. EMBO Journal, v.6, n.2, p.295-302, 1987. 
CHOWDHURY, M.K.; SCHAEFFER, G.W.; SMITH, R.F. Molecular analysis of organelle DNA of different subspecies of rice and genomic stability of $\mathrm{mt}$ DNA in tissue culture cells of rice. Theoretical and Applied Genetics, v.76, p.533-539, 1988.

CLOTIER, S.; LANDRY, B.S. Molecular markers applied to plant tissue culture. In vitro Cellular and Developmental Biology, v. 30, p. $32-39,1994$.

CUTRIM, V.A. Eficiência da seleção visual na produtividade de grãos de arroz (Oryza sativa L.) irrigado. Lavras, 1994. 92p. Tese (Doutorado) - Escola Superior de Agricultura de Lavras.

D'AMATO, F. Cytogenetics of differentiation in tissue cultures. In: REINERT, J.; BAJAJ, Y.P.S. (Ed.) Plant cell, tissue, and organ culture. Berlin: Springer-Verlag, 1977. p.343-357.

D'AMATO, F. Cytogenetics of plant cell and tissue cultures and their regenerates. CRC Critical Review Plant Science, v.3, p.73-112, 1985.

EDALLO, S.; ZUCCHINALI, C; PERENZIN, M.; SALAMINI, F. Chromosomal variation and frequency of spontaneous mutation associated with in vitro culture and plant regeneration in maize. Maydica, v.26, n. 1, p.39-56, 1981.

EMPRESA BRASILEIRA DE PESQUISA AGROPECUÁRIA. Centro Nacional de Pesquisa de Arroz e Feijão. Manual de métodos de pesquisa em arroz. Goiânia, 1977. 106p (primeira aproximação 
EMPRESA BRASILEIRA DE PESQUISA AGROPECUÁRIA. Programa Nacional de Avaliação de Linhagens de Arroz. Brasilia: EMBRAPA CNPAF, 1994, 19p. (Documento,41)

EMPRESA BRASILEIRA DE PESQUISA AGROPECUÁRIA. Informativo anual das comissões técnicas regionais de arroz: Cultivares de arroz recomendadas para plantio no ano agrícola 1997/98. 1997.

EVANS, D.A.; SHARP, W.R. Applications of somaclonal variation. Bioltechnology, v.4, n.6 p. 528-532, 1986.

EVANS, D.A; SHARP, W.R.; MEDINA-FILHO, H.P. Somaclonal and gametoclonal variation. American Journal Botany., v.71, p.759-774, 1984.

FAO - QUATERLY BULLETIN OF STATISTICS, 10: 3/4, 1997.

FALCONER, D.S. Introdução à genética quantitativa. Viçosa: UFV, Imprensa. Universitária., 1978. 279p.

FEDOROFF, N.V. Maize transposable elements. In: BERG, D.E.; HOWE, M. M. Mobile DNA. Washington: American Society for Microbiology, 1989. p. 375-407.

FEDOROFF, N.V.; CHANDLER, V. Inactivation of maize transposable elements, In: PASZKOWSKI, J. (Ed.) Homologous recombination and gene silencing in plants, Dordrecht: Kluwer, 1994. p. 349-385. 
FEDOROFF, N.V.; SHLÄPPI, M.; RAINA, R. Epigenetic regulation of the maize Spm transposon. BioEssays, v. 17, p. 291-297, 1995.

FERREIRA, M.E.; CALDAS, L.S.; PERREIRA, E.A. Aplicações da cultura de tecidos no melhoramento genético de plantas. In: TORRES, A.C.; CALDAS, L.C.; BUSO J.A. Cultura de tecido e transformação genética de plantas. Brasilia: CBAB/EMBRAPA, 1998. v.1, p.21-43.

FERREIRA,D.F.; ZAMBALDE, A.L Simplificacão das análises de algumas técnicas especiais da experimentacão agropecuária no MAPEGEM e Software correlatos. In: CONGRESSO DA SOCIEDADE DE INFORMÁTICA APLICADA A AGROPECUÁRIA E AGROINDÚSTRIA, V.1,Belo Horizonte,1997. Anais Belo Horizonte:SBI, 1997. p.285-291

FISH, N.; KARP, A. Improvement in regeneration from protoplasts of potato and studies on chromosome stability 1. The effect of initial culture media. Theoretical and Applied Genetics, v. 72, p. $405-412,1986$.

FLUMINHAN JUNIOR, A.; AGUIAR-PERECIN, M.L.R.; SANTOS, J. A. Evidence for heterochromatin involvement in chromosome breakage in maize callus culture. Annals of Botany, v.78, p.73-81, 1996.

FLUMINHAN JÚNIOR, A.; KAMEYA, T. Behavior of chromosomes in anaphase cells in embryogenic callus cultures of maize (Zea mays L.) Theoretical and Applied Genetics, v.92, p.982-990, 1996. 
GERMEK, E.B.; BANZATTO, N.V. Melhoramento do Arroz no Instituto Agronômico., Boletim, n. 202, 1972. 56p

GERMEK, E.B.; BANZATTO, N.V. Realizações do Instituto Agronômico - Participações da variedade paulista de arroz de sequeiro IAC 1246 na produção nacional. O agronómico, v.29/30 .p.33-40, 1977.

GOMES, P.F. Curso de estatística experimental. 13.ed. Piracicaba: Nobel, 1987. 468p.

GUIMARÃES, E.P. Qualidade de grão em arroz. Documento apresentado na VII reunião da Comissão Técnica de Arroz da Região II. Campinas, 1989. 13 p. (mimeografado)

HARDING, K.; BENSON, E. E.; ROUBELAKIS-ANGELAKIS, K. A. Methylated DNA changes associated with the initiation and maintenance of Vitis vinifera in vitro shoot and callus cultures: A possible mechanism for age-related changes. Vitis, v. 35, n. 2 , p. $79-85,1996$.

HESLOP-HARRISON, J. S.; BRANDES, A.; TAKETA, S.; SCHIMIDT, $T$. et al. The chromosomal distribution of Ty1/copia group retrotransposable elements in higher plants and their implications for genome evolution. Genetica, v. 100, p. 197204, 1997.

HIROCHIKA, H. Activation of tabacco retrotransposon during tissue culture. EMBO Journal, v. 12, n. 6, p. 2521-2528, 1993. 
HIROCHIKA, H. Regulation of plant retrotransposons and their use for genome analysis. Gamma Field Symposia, n. 34,1995.

HIROCHIKA, H.; SUGIMOTO, K.; OTSUKI, Y.; TSUGAWA, H.; KANDA, M. Retrotransposon of rice involved in mutations induced by tissue, culture. Proceedings of the National Academy Science of the United States of America, v. 97, p. 7783-7788, 1996.

HOLLIDAY, R. The inheritance of epigenetic defects. Science, $v$. 238, p. 163-169, 1987.

JOACHIMIAK, A.; PRZYWARA, L.; ILNICKI, T.; KOWALSKA, A. Megachromosomes in tissue culture of Allium. Genetica, v. 90, p. $35-40,1993$.

KAEPLER, S.M.; PHILLIPS, R.L. Tissue culture-induced DNA methylation variation in maize. Proceeding of the National Academy of Sciences of the United States of America, v.90, p. 8773-8776, Oct.1993.

KHUSH, G.S. Origin, dispersal, cultivation and variation of rice. Plant Molecular Biology, v. 35, p. 25-34, 1997.

KUNITAKE, $H_{\text {; }}$ N NAKASHIMA, T.; MORI, K. TANAKA, M. Somaclonal and chromosomal effects of genotype, ploidy and culture duration in Asparagus officinalis L. Euphytica, v. 102, p. 309-316, 1998. 
KUNZE, R; SAEDLER, H.; LÖNNING, W. E. Plant transposable elements. Classic Papers Advances in Botanical Research, v. 27, p. $332-436,1997$.

LARKIN, P. J.; SCOWCROFT W. R. Somaclonal variation - a novel source of variability from cell cultures for plant improvement. Theoretical and Applied Genetics, v.60, p.197-214, 1981.

LEE, M.; PHILLIPS, R.L. Genomic rearrangements in maize induced by tissue culture. Genome, v.29, n. 1, p. 122-128, 1987 a.

LEE, M.; PHILLIPS, R.L. The chromosomal basis of somaclonal variation. Annual Review of Plant Physiology and Plant Molecular Biology, v.39, p.413-437, 1988.

LEWIN, B. Genes V Oxford: University Press, 1994. cap. 28, p. 797-844: Chromosomes consist of nucleossomes.

LOSCHIAVO, F.; PITTO, L.; GIULIANO, G.; TORTI, G.; NUTIRONCHI, V.; MARAZZITI, D.; VERGARA, R.; ORSELLI, S.; TERZI, M. DNA methylation of e mbryogenic carrot cell cultures and its variations as caused by mutation, differentiation, hormones and hypomethylating drugs. Theoretical and Applied Genetics, v. 77, p. 325-331, 1989.

MALUSZYNSKI, M.; VAN ZANTEN, L.; ASHRI, A ; BRUNNER, H.; AHLOOWALIA, B.; ZAPATA, F.J.; WECK, E. Mutation techniques in plant breeding. In: INTERNATIONAL ATOMIC ENERGY AGENCY, Induced mutations and molecular techniques for crop improvement, Vienna: IAEA, p. 490-504, 1995. 
MANTELL, S.H.; MATTHEWS; J.A.; McKeE, R.A. Principios de biotecnologia em plantas: uma introdução à engenharia genética em plantas. Ribeirão Preto: Sociedade Brasileira de Genética,1994. 344p.

MCCLINTOCK, B. The stability of broken end of cromosomes in Zea mays, Genetics, v.26, p.234-282, 1941.

MCCLINTOCK, B. The significance of responses of the genome challenge. Science, v. 226, p. 792-801, 1984.

MCKENZIE, K.S.; BOLLICK, N.C.; RUTGER, J.N.; MOLDENHAUER, K.A.K. Rice. In: FEHR, W.R. Principles of cultivar development. New York: Mac-Millam 1987 cap.13, p. 487-532.

MEINS JUNIOR, F. Heritable variation in plant cell culture. Annual Review Plant Physiology, v.43, p.327-346, 1983.

MONTALVÁN, R.; ANDO, A. Effect of gamma-radiation and sodium azide on quantitative characters in rice (Oryza sativa L.). Genetics and Molecular Biology, v. 21, n.1 p.81-85, 1998.

MONTALVÁN, R.; DESTRO, D.; SILVA, E.F.; MONTAÑO, J.C. Genetic base of Brazilian upland rice cultivars. Journal Genetics. \& Breeding, v.52, p.203-209, 1998.

MORAES, O. P.; CASTRO, E.M.; SANT'ANA, E.P. Selección recurrente aplicada al arroz de riego en Brasil. In: GUIMARÃES, E.P. Seleccion recurrente en arroz. Cali: CIAT,1997. p.79-98. 
MOURA, D.S. Regeneração de plantas de cultivares brasileiro de arroz (Oryza sativa L.) a partir de protoplastos de calos de embrião maduro. Piracicaba, 1994. 141p. Dissertação (Mestrado) - Escola Superior de Agricultura "Luiz de Queiroz", Universidade de São Paulo.

MOURA, D.S.; ZAPATA-ARIAS, F.J.;ANDO, A; TULMA NETO, A. Plant regeneration from protoplasts isolated from primary callus using mature embryos of two Brazilian rice cultivars. Euphitica, v.94, n.1, p.1-5, 1997.

NEVES, P.C.F.; CASTRO, E.M.; RANGEL, P.H.N.; YOKOYAMA, L.P. Hybrid rice research in Brazil. In: VIRMANI, S.S. Hybrid rice tecnhnology: ew developments and future prospects. International Rice Research Institute, Manila, Philippines, 1994. p.249-252.

OHIRA, K.; OJIMA, K.; FUJIWARA, A. studies on the nutrition of rice cell culture I. A simples defined medium of rapid growth in suspension culture. Plant and Cell Physiology. v14, p1113$1121,1973$.

OGURA, H.; KYOZUKA, J.; HAYASHI, Y.; KOBA, T.; SHIMAMOTO, K. Field performace and cytology of protoplast-derived rice (Oryza sativa): high yield and low degree of variation of four japonica cultivars. Theoretical and Applied Genetics, v.74 p.670-676, 1987.

PACOVA, B.E.V. Análise genética de progênies segregantes de soja apropriada para o consumo humano. Piracicaba. 1992. 122p. Tese (Doutorado) - Escola Superior de Agricultura "Luiz de Queiroz", Universidade de São Paulo. 
PALMER, J. D.; SHIELDS, C. R. Tripartire structure of the Brassica campestris mitocondrial genome. Nature, v. 307, p. 437-440, 1984.

PESCHKE, V. M.; PHILLIPS, R. L.; GENGENBACH. B. G. Genetic and molecular analysis of tissue-culture-derived Ac elements. Theoretical and Applied Genetics, v. 82, p. 121-129, 1991.

PESCHKE, V.M.; PHILLIPS, R.L. Genetic implications of somaclonal variation in plants. Advances in Genetics, v.30, p.41-75, 1992.

PHILLIPS, R.L., KAEPPLER, S.M.; PESCHKE V.M. Do we understand somaclonal variation? Progress in Plant Cellular and Molecular Biology. In: INTERNATIONAL CONGRESS ON PLANT TISSUE AND CELL CULTURE, Amsterdam, 1990.

PHILLIPS, R.L.; KAEPPLER, S.M.; OLHOFT, P. Genetic instability of plant tissue cultures: Breakdown of normal controls. Proceedings of the National Academy Sciences of the United States of American, v.91, n.12, p.522-526, 1994.

PHILLIPS, R.L.; SOMERS, D.A.; HIBBERD, K.A. Cell/tissue culture and in vitro manipulation. In: SPRAGUE. G.F.; DUDLEY, J.W. (Ed.) Corn and corn improvement. 3.ed. Madison: ASA/CSSA/SSSA, 1988. p.345-387. (Agronomy Monographs, 18). 
RANGEL, P.H.N. Eficiência da seleção simultânea de arroz (Oryza sativa L.) em várzeas, com e sem irrigação controlada. Piracicaba, 1990. 125p. Tese (Doutorado) - Escola Superior de Agricultura "Luiz de Queiroz", Universidade de São Paulo.

RANGEL, P.H.N.; GUIMARÃES, E.P.; NEVES, P.C.F. Base genética das cultivares de arroz (Oryza sativa L.). Irrigado do Brasil. Pesquisa Agropecuária Brasileira, v. 31, p. 349-357, 1996.

RANGEL, P.H.N.; NEVES, P.C.F. Selección recurrente aplicada al arroz de secano en Brasil. In: GUIMARÃES, E.P. Seleccion recurrente en arroz. Cali CIAT,1997. p.99-115.

RESENDE, M.H. Origem do arroz em Pelotas. Lavoura Arrozeira, v. 29, n. 289, p. $13-14,1976$.

RODE, A.; HARTMANN, C.; HENRY, Y.; DE BUYSER, J.; AUBRY, C.; AUBRY, C. Identification of new mitochondrial genome organizations in wheat plants regenerated from somatic tissue cultures. Theoretical and Applied Genetics, v. 77, p. 169-175, 1989.

SALEH, N. M.; GUPTA, H. S.; FINCH, R. P. Stability of mitochondrial DNA in tissue-cultured cell rice. Theoretical and Applied Genetics, v. 79 , p. 342-346,1990.

SANTOS, J. A. Estudo da instabilidade cromossômica em cultura de longa duração de calos de milho. Piracicaba, 1995. 172p. Tese (Mestrado) - Escola Superior de Agricultura "Luiz de Queiroz", Universidade de São Paulo. 
SCHWARTZ, D, Gene-controlled cytosine demethylation in the promoter region of the Ac transposable element in maize. Proceedings of the National Academy Sciences of the United State of American,v.86, n.8, p.2789-2793, Apr. 1989.

SCORTECCI, K. C.; DESSAUX, Y.; PETIT, A.; VAN SLUYS, M-A. Somatic excision of the Ac transposable element in transgenic Arabidops thaliana after 5-azacytidine treatment. Plant Cell Physiology, v. 38, n.3, p. 336-343, 1997.

SCOTT, A.J.; KNOTT, M. A cluster analysis method for grouping means in the analysis of variance. Biometrics, v.30, p.507$512,1974$.

SCOWCROFT, W. R.; DAVIS, P.; RYAN, S. A.; BRETTELL, R. I .S.; PALLOTTA, M. A.; LARKIN, P .J. The analysis of somaclonal mutants. In: FREELING, M.; ALAN, R. (Ed.) Plant genetics. New York: 1985. p.799-815.

SILVA, E.F. Caracterização de linhagens mutantes de arroz de sequeiro obtidas com utilização da azida sódica $\left(\mathrm{N}_{\mathrm{a}} \mathrm{N}_{3}\right)$. Piracicaba, 1994. 57p. Dissertação (Mestrado) - Escola Superior de Agricultura "Luiz de Queiroz", Universidade de São Paulo.

SILVAROLLA, M. B. Plant genomic alterations due to tissue culture. Ciência e Cultura, v.44, p.329-335, 1992.

SOARES, A.A.; REIS, M.S.; SOARES, P.C. Caipó, nova opção de arroz de sequeiro para Minas Gerais. Revista Ceres, p.231-17, 1993. 
SYBENGA, J. Cytogenetics in plant breeding. Berlin: SpringerVerlag, 1992, cap.3, p.23-63: The mechanisms of genetic transmission.

TAVARES, M. Comparação de delineamentos experimentais na avaliação de progênies de meios irmãos de cenoura. Piracicaba. 1998. 89p. Tese (Doutorado) - Escola Superior de Agricultura "Luiz de Queiroz", Universidade de São Paulo

TUlmANn NETO, A.; MENDES, B.M.J.; ANDO, A. Progresso na indução e uso de mutação in vitro. In: TORRES, A.C.; CALDAS, L.C.; BUSO J.A. Cultura de tecido e transformação genética de plantas. Brasília: CBAB/EMBRAPA,1998. v.1, p. $21-43$

VENCOVSKY, R. Herança quantitativa. In: PATERNIANI, E.; VEIGAS, G.P. Melhoramento de milho no Brasil. 2.ed. Campinas: Fundação Cargil, 1987 p.137-209

VIÉGAS, G.P.; GERMEK, E.B.; MIRANDA, H.S. Contribuição para a melhoria da rizicultura no estado de São Paulo. Bragantia, v5, n.3, p.187-196, 1945

YAMAGISHI, M.; ITOH, K.; KOBA, T.; SUKEKIYO, Y.;SHIMAMOTO, K.; SHIMADA, T. Characteristics of genetic variation in the progenies of protoplast-derived plants of rice, Oryza sativa cv. Nipponbare. Theoretical and Applied Genetics, v.94, n.1, p.1-7, 1997 
YAMAGISHI, M.; OTANI, M.; SHIMADA, T. A comparison of somaclonal variation in rice plants derived and not derived from protoplasts. Plant Breeding, v.115, p.289-294, 1996.

ZONG-XIU, S.; CHENG-ZHENG, Z.; KANG-LE, Z.; XIU-FANG, Q.; YA-PING, F. Somaclonal genetics of rice, Oryza sativa L. Theoretical and Applied Genetics, v.67,p.67-73, 1983.

ZONGXIU, S.; LIHUA, S.; LIHUI, S. Utilization of somaclonal variation in rice breeding. In: BAJAJ, Y. P.S. Biotechnology in agriculture and Forestry 14. Berlin: Springer-Verlag, 1991. $p$ 328-346. 